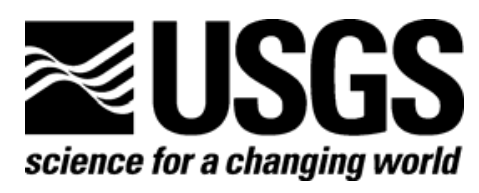

\title{
PERU MERCURY INVENTORY 2006
}

By William E. Brooks, ${ }^{1}$ Esteban Sandoval, ${ }^{2}$ Miguel A. Yepez, ${ }^{2}$ and Howell Howard ${ }^{2}$

Open File Report 2007-1252

U.S. Department of the Interior

U.S. Geological Survey

${ }^{1}$ U.S. Geological Survey, Reston, VA 20192

${ }^{2}$ U.S. Embassy Lima, Peru 


\title{
U.S. Department of the Interior DIRK KEMPTHORNE, Secretary
}

\author{
U.S. Geological Survey \\ Mark D. Myers, Director
}

U.S. Geological Survey, Reston, Virginia 20192

For product and ordering information:

World Wide Web: http://www.usgs.gov/pubprod

Telephone: 1-888-ASK-USGS

For more information on the USGS - the Federal source for science about the Earth, its natural and living resources, natural hazards, and the environment:

World Wide Web: http://www.usgs.gov

Telephone: 1-888-ASK-USGS

Suggested citation:

Brooks, W.E., Sandoval, E., Yepez, M.A., Howell H., 2007, Peru mercury inventory 2006:

U.S. Geological Survey Open-File Report 2007-1252, 55 p.,

available online at http://pubs.usgs.gov/of/2007/1252/.

Any use of trade, product, or firm names is for descriptive purposes only and does not imply endorsement by the U.S. Government.

Although this report is in the public domain, permission must be secured from the individual copyright owners to reproduce any copyrighted material contained within this report. 


\section{Contents}

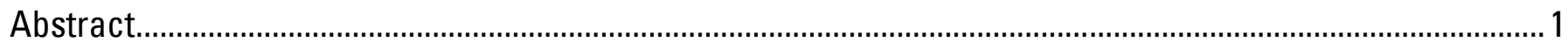

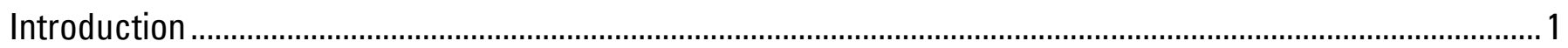

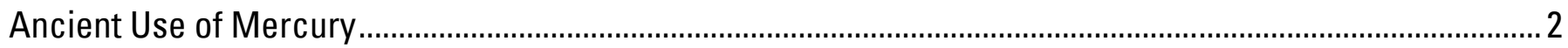

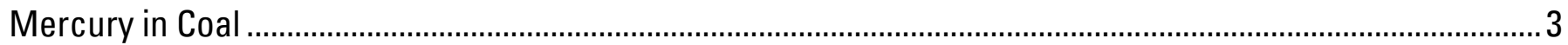

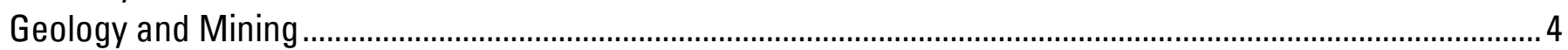

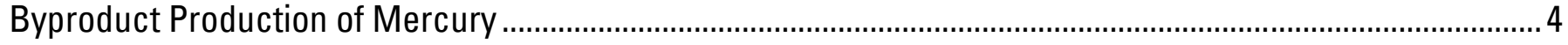

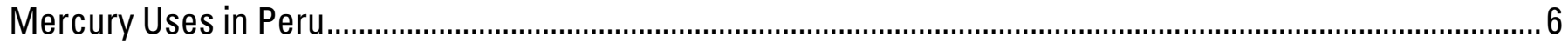

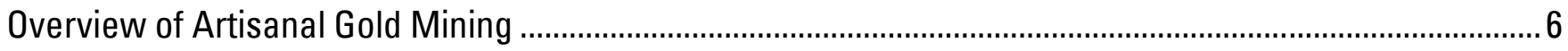

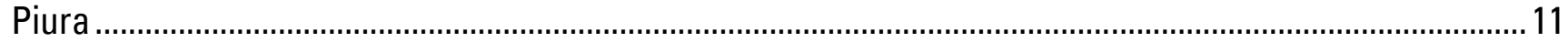

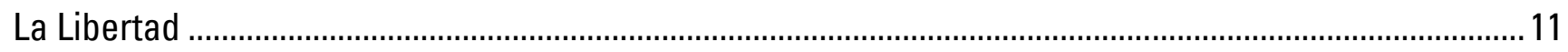

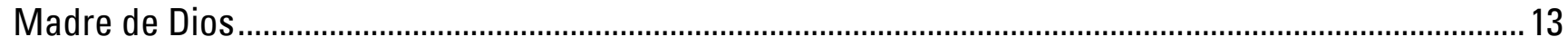

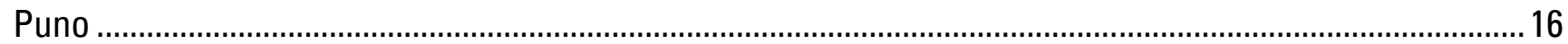

Ananea

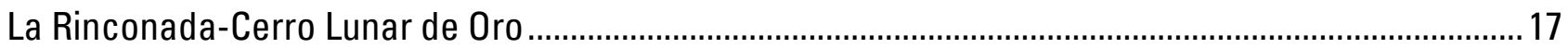

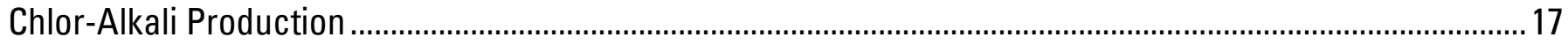

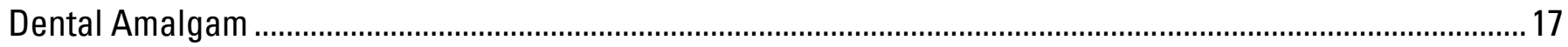

Other Uses and Disposition of Imported Mercury-Containing Products .......................................................... 18

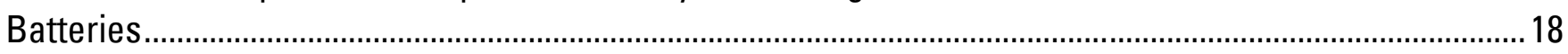

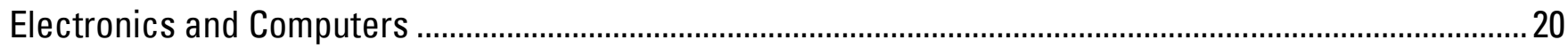

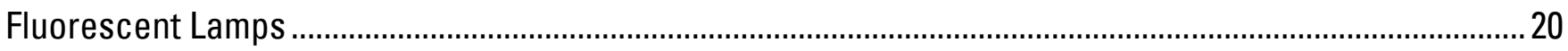

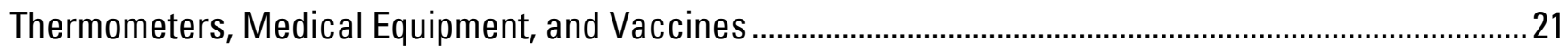

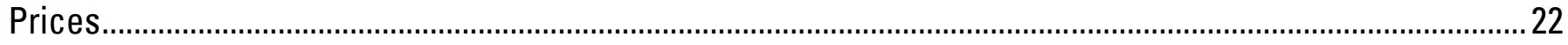

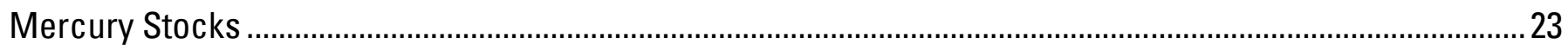

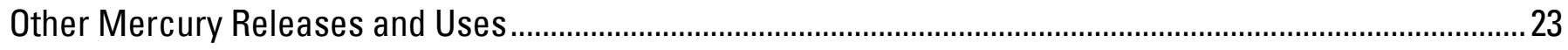

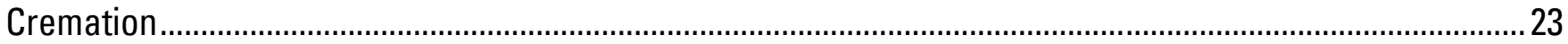

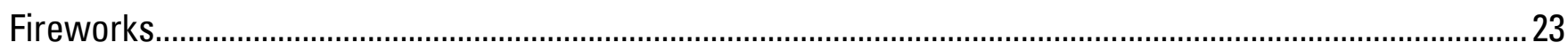

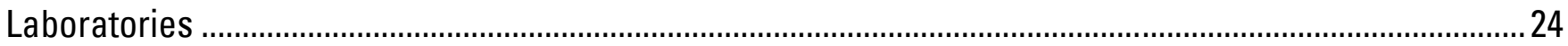

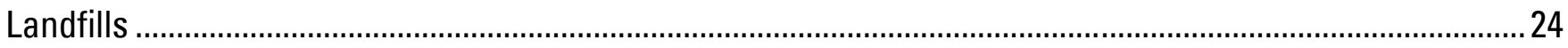

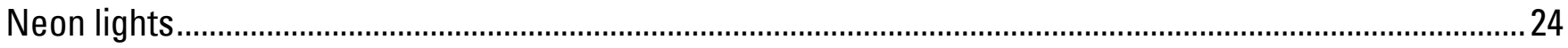

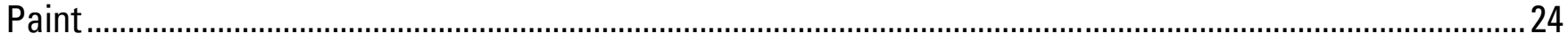

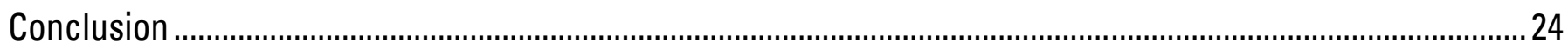

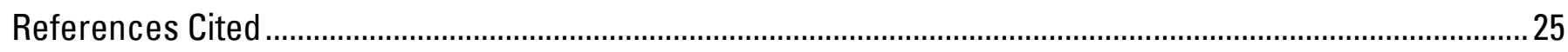

\section{Figures}

1. Security container with flasks of byproduct mercury before leaving Newmont Mining Corporation's Yanacocha mine, northern Peru. (Photograph permission of Newmont Mining Corporation)... 
2. Unvented mercury retort for gold processing in a grocery store in Inambari, Madre de Dios, Peru. (Photograph by William E. Brooks)..

3. Sealable mercury retort at Mina Cabecera Santa Ynes, Huepethue, Madre de Dios, Peru. Tube on side helps to capture some of the volatized mercury fumes. (Photograph by William E. Brooks)..

4A.) Mercury retort, with B) a chimney to vent mercury fumes outside, in a gold shop in Huepethue, Madre de Dios, Peru. (Photographs by William E. Brooks).

5. Mercury reactivator for cleaning and recycling mercury by using electricity from a 12 volt battery. (Photograph by William E. Brooks).

6A.) Sluice and B) silvery, mercury-gold amalgam in gold pan (batea) in foreground at Mina Cabecera Santa Ynes, Huepethue, Madre de Dios, Peru. (Photographs by William E. Brooks)..

7A) Gold immediately after being removed from the retort and B) gold after being burned (refogado) to remove any mercury and improve the aesthetic appearance of the gold, Mina Cabecera Santa Ynes, Huepethue, Madre de Dios, Peru. (Photographs by William E. Brooks)..

8. Widely used "El Español" brand of recycled mercury. (Photograph by William E. Brooks)... 15

9. Battery collection for recycling, an environmental project by students at Colegio Roosevelt, Lima, Peru in collaboration with Supermercados Wong, S.A., a major grocery chain and Teconec, S.A.C., an environmental consulting firm in Lima, Peru. (Photograph courtesy of Sarah Kemme, instructor, Colegio Roosevelt, Lima, Peru)..

10. Discarded fluorescent lamp on the street, Trujillo, Peru. (Photograph by William E. Brooks).. 21

11. Mercury thermometer bought in a drugstore in Lima, Peru. (Photograph by William E. Brooks).

\section{Tables (1-15)}

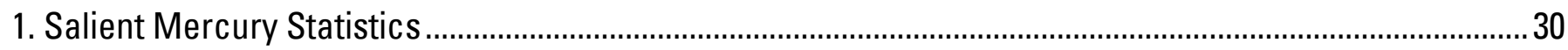

2. Imports and Exports of Mercury, by Country .........................................................................................

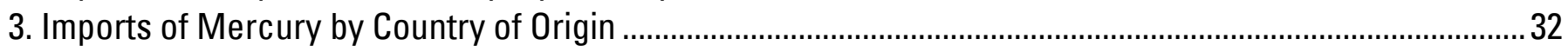

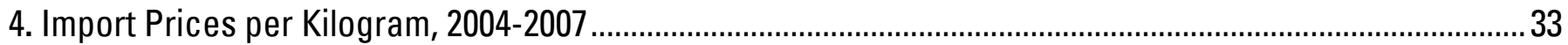

5. Import Mercury Average Price 2004-2007 ……………………………………………........................ 34

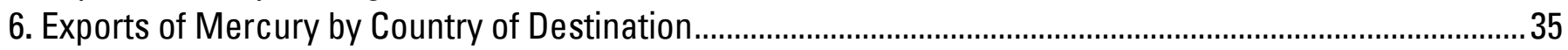

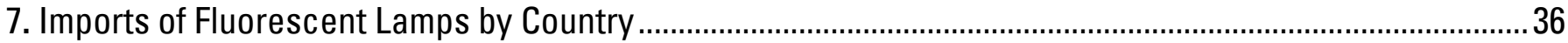

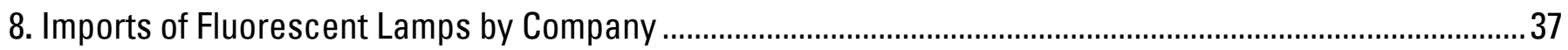

9. Imports of Non-Electric Thermometers by Company …………………………………………………..... 40

10. Imports of Batteries, Manganese Dioxide, Alkaline ………...................................................................... 44

11. Imports of Other Batteries, Manganese Dioxide, Alkaline ……………..................................................... 45

12. Imports of Other Batteries, Manganese Dioxide, Cylindrical ........................................................................4 46

13. Harmonized Tariff Codes for All Batteries …………………………………………………………........ 47

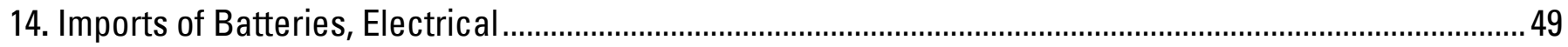

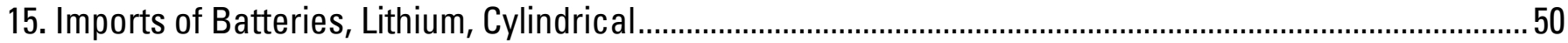




\section{Conversion Factors}

\begin{tabular}{lll}
\hline \multicolumn{1}{c}{ Multiply } & By & \multicolumn{1}{c}{ To obtain } \\
\hline centimeter $(\mathrm{cm})$ & 0.3937 & inch (in.) \\
gram $(\mathrm{g})$ & 0.03527 & ounce, avoirdupois (oz) \\
kilogram $(\mathrm{kg})$ & 2.204 & pounds \\
kilograms per year $(\mathrm{kg} / \mathrm{yr})$ & 2.204 & pounds per year \\
kilometer $(\mathrm{km})$ & 0.6214 & mile (mi) \\
liter $(\mathrm{L})$ & 33.82 & ounce, fluid (fl. oz) \\
meter $(\mathrm{m})$ & 3.281 & foot (ft) \\
metric ton $(\mathrm{t})$ & 1.10231 & short ton \\
metric ton per year $(\mathrm{t} / \mathrm{yr})$ & 1.102 & ton per year (ton/yr) \\
square kilometer $\left(\mathrm{km}^{2}\right)$ & 247.1 & acre
\end{tabular}

Temperature in degrees Celsius $\left({ }^{\circ} \mathrm{C}\right)$ may be converted to degrees Fahrenheit $\left({ }^{\circ} \mathrm{F}\right)$ as follows:

${ }^{\circ} \mathrm{F}=\left(1.8 \times{ }^{\circ} \mathrm{C}\right)+32$ 


\title{
PERU MERCURY INVENTORY 2006
}

\author{
By William E. Brooks, Esteban Sandoval, Miguel A. Yepez, and Howell Howard
}

\section{Abstract}

In 2004, a specific need for data on mercury use in South America was indicated by the United Nations Environmental Programme-Chemicals (UNEP-Chemicals) at a workshop on regional mercury pollution that took place in Buenos Aires, Argentina. Mercury has long been mined and used in South America for artisanal gold mining and imported for chlor-alkali production, dental amalgam, and other uses.

The U.S. Geological Survey (USGS) provides information on domestic and international mercury production, trade, prices, sources, and recycling in its annual Minerals Yearbook mercury chapter.

Therefore, in response to UNEP-Chemicals, the USGS, in collaboration with the Economic Section of the U.S. Embassy, Lima, has herein compiled data on Peru's exports, imports, and byproduct production of mercury. Peru was selected for this inventory because it has a 2000-year history of mercury production and use, and continues today as an important source of mercury for the global market, as a byproduct from its gold mines. Peru is a regional distributor of imported mercury and user of mercury for artisanal gold mining and chlor-alkali production.

Peruvian customs data showed that 22 metric tons $(\mathrm{t})$ of byproduct mercury was exported to the United States in 2006. Transshipped mercury was exported to Brazil (1 t), Colombia ( $1 \mathrm{t})$, and Guyana (1 t). Mercury was imported from the United States (54 t), Spain (19 t), and Kyrgyzstan (8 t) in 2006 and was used for artisanal gold mining, chlor-alkali production, dental amalgam, or transshipment to other countries in the region. Site visits and interviews provided information on the use and disposition of mercury for artisanal gold mining and other uses.

Peru also imports mercury-containing batteries, electronics and computers, fluorescent lamps, and thermometers. In 2006, Peru imported approximately 1,900 t of a wide variety of fluorescent lamps; however, the mercury contained in these lamps, a minimum of approximately 76 kilograms (kg), and in other products such as batteries and computer electronics is not recycled and may ultimately be released to the environment.

\section{Introduction}

Throughout history, mercury has been known and used for gold and silver processing. In Peru and many parts of the world, mercury is now used in batteries, chlor-alkali production, dental amalgam, fluorescent lights, switches, and thermometers. Much of the mercury contained in these end-of-use products can be recycled (Brooks and Matos, 2005); however, only a small amount of the mercury used for artisanal gold mining is recycled.

Mercury, the liquid metal, occurs naturally in a number of geologic environments, may be obtained as a byproduct from precious metals mining, or is found in trace amounts in coal. Much of this mercury may be used and recycled; however, mercury used for artisanal gold production and mercury released from coal-fired powerplants, broken fluorescent lamps, and other sources is not recovered and becomes a global environmental and human health concern. 
In 2001, the Global Environment Facility allocated funding for studies related specifically to mercury use for artisanal gold mining in six countries from three continents. In order to focus awareness on human health issues, mercury releases, and regional mercury pollution, a United Nations Environmental Programme-Chemicals (UNEP-Chemicals) workshop took place in Buenos Aires, Argentina, in 2004. UNEP-Chemicals indicated a specific need for data and information on mercury production and use of mercury for artisanal gold mining in South America. Minimizing mercury contamination in the Amazon Basin was the theme of meetings held in Rio de Janeiro, Brazil, in December 2004 and in Lima, Peru, in February 2005. Sources of contamination, ecotoxicity, and human health issues were discussed by attendees from Bolivia, Brazil, Colombia, Ecuador, Peru, Suriname, and Venezuela. These meetings were sponsored by the Amazon Cooperation Treaty Organization (Brazil), the Andean Community (Peru), the Ministry of Environment (Brazil), and the Regional Environmental Program of the Department of State-U.S. Embassy, Brasilia, Brazil.

In 2006, Peru ranked first in gold production in Latin America and fifth in world gold production as well as being a world leader in silver, zinc, copper, and tin production. Therefore, because of environmental awareness and mercury stewardship on the part of Peru's major international mining companies, Peru became a leader in reduction of mercury emissions and byproduct mercury recovery from their large scale open-pit mines (Barrick Gold Corporation, 2005, p. 14). Byproduct mercury and calomel $\left(\mathrm{Hg}_{2} \mathrm{Cl}_{2}\right)$, which is recovered from precious metals processing in Peru and elsewhere in South America, are exported to the United States for processing, and the mercury is resold into the world market, where it may be used for a variety of uses. Peru also imports mercury for artisanal mining, chlor-alkali production, and dental amalgam. Mercury is also imported as a component of batteries, electronics, fluorescent lamps, medical equipment, and thermometers.

The U.S. Embassy, Lima requested an in-country, field inventory of commodity mercury in Peru through the U.S. Department of State's Embassy Science Fellow Program. This was in response to the need for mercury information in the region indicated by UNEP-Chemicals at environmental meetings in Rio de Janiero and Lima, and Peru's leading role in gold mining, byproduct production of mercury, and widespread use of mercury for artisanal gold mining in Peru.

\section{Ancient Use of Mercury}

Mercury and the ore of mercury, cinnabar, were known to and used by ancient people in Asia, Europe, and South America. Geologically, mercury and cinnabar are well-known at Almaden, Spain; Huancavalica, Peru; Idrija, Slovenia; in the Yangtze belt, China; and other locations. Archaeologists have shown that mercury was used for gold amalgamation by the Romans, and cinnabar was used for funeral preparations and as a multi-use pigment.

Near Valencia, Spain, well-preserved human bones covered with powdered cinnabar were found in a tomb that dates to 5000 B.C. (Maravelaki-Kalaitzaki and Kallithrakas-Kontos, 2003). Mercury was found in a ceremonial cup in an Egyptian tomb that dates to 1600 B.C. and the Greeks retorted mercury from cinnabar in 300 B.C. Archaeologists have described an underground tomb in China that dates to 200 B.C. and it is described as having flowing rivers of mercury (China History Forum, 2006; Saiget, 2007).

Roman villas were decorated with pigments made from powdered cinnabar, which was also used for makeup and, by A.D. 77, 4 to $5 \mathrm{t}$ of mercury were imported annually from the mines in Spain for gold amalgamation. Roman slaves and criminals were sent to work, and subsequently to die, from the toxic mercury fumes released by firesetting (an ancient mining practice in which wood was burned at the face of the ore zone and water was poured on the face causing the rock to spall and crack) in the Spanish mercury mines (D'Itri and D'Itri, 1977, p. 6). In Central America, jade and shell fragments were found floating on a tiny, approximately 130-gram (g) pool of mercury in a closed container in a Mayan tomb in Belize that dates to A.D. 900-1000 (Pendergast, 1982).

Mercury was known in ancient Peru and used by the Moche (approximately 100 B.C.-A.D. 750) in northern Peru to amalgamate placer gold and for the production of gold artifacts (Kaufmann Doig, 1978, 
p. 747; Larco Hoyle, 2001, p. 128). Mercury was recovered from drainages near the mercury occurrences at Huancavelica, and possibly from retorting cinnabar (Petersen, 1970, p. 55). Whether or not the ancient Andeans retorted cinnabar for mercury is controversial; however, retorts have been identified near the mines at Huancavelica (K. Brown, professor, Brigham Young University, written commun., May 9, 2003). Powdered cinnabar was used to decorate gold masks during the Formative Period (400-1000 B.C.) (De Lavalle, 1992, p. 39); as a mineral pigment used on murals (Muelle and Wells, 1939, p. 27; Brooks and others, 2006b); for painting warriors bodies and as a cosmetic for the elite Inca women (Brown, 2001, p. 477); and also for funeral preparations (Maravelaki-Kalaitzaki and Kallithrakas-Kontos, 2003; Jackson, 2004; J. Verano, Ph.D., anthropologist, Dumbarton Oaks, Washington, D.C., oral commun., December 12, 2005).

Approximately 20 mercury occurrences are known in Peru (Petersen, 1970, p. 55) and there are occurrences in southern Ecuador, near Cuenca and Azoguines (Truhan and others, 2005); however, the occurrences at Huancavelica are the largest and most well-known in the region and are the most likely source of mercury and cinnabar used in the ancient Andes. Only 15 kilometers $(\mathrm{km})$ from the mine is Atalla, an archaeological site which was interpreted as an ancient cinnabar pigment production center (Burger and Matos, 2002, p. 10). As did the Romans, the Inca recognized the health hazards of mercury and that exposure to mercury and cinnabar during mining and retorting would cause the ancient miners "to shake and lose their senses" and, therefore, the use of mercury by the Inca declined (Larco Hoyle, 2001, p. $135)$.

Originally, Spain transported mercury from the mines at Almaden for mineral processing in the New World, and Spanish shipwrecks that still contain mercury are known in the Dominican Republic and in Colombia (Petersen, 1979, p. 851). However, upon re-discovery of the mercury occurrences at Huancavelica by the Europeans in the 1600s (Arana, 1901, p. 77), this regional source soon replaced imported Spanish mercury. Because of the combination of dangerous mining conditions, cold, working at 4,000 meters ( $\mathrm{m}$ ), and exposure to the toxic mercury fumes, Huancavelica was known as the "mina de la muerte" [the mine of death] (Brown, 2001, p. 468). Regardless, mercury's role was important for mineral processing in Spanish Colonial Peru and adding mercury, "el azogado" [azogue is an Arabic term for mercury that is commonly used in many parts of Latin America], was an essential step in silver recovery (Del Busto Duthurburu, 1996, p. 98).

Mercury from Huancavelica was also used in the "patio process" for silver processing in Chile, Bolivia, and Mexico. Salt, mercury, and vitriol (mixed copper and iron sulfates) were mixed with crushed silver ore that contained argentite $\left(\mathrm{Ag}_{2} \mathrm{~S}\right)$, cerargyrite $(\mathrm{AgCl})$, or pyragyrite $\left(\mathrm{Ag}_{3} \mathrm{SbS}_{3}\right)$, also known as the "dry ores," in a large open area, or patio, and at Potosí, Bolivia, the cold climate required that the patios be heated from below to speed silver production (Craddock, 1995, p. 216).

\section{Mercury in Coal}

Mercury and other metals such as arsenic are contained in trace amounts in coal, and mercury is released when the coal is burned in a coal-fired powerplant. The quantity of mercury contained in coal is typically small; however, the volume of coal that is burned yearly indicates that tons of mercury may be released and this is a concern for the environment and human health. For example, the thousands of coal-fired powerplants in the United States are estimated to release approximately $48 \mathrm{t}$ of mercury annually (Gugliotta, 2004). Powerplants in coal-using nations such as China also contribute to global mercury releases; however, there is no recovery of this mercury.

Coal is widely distributed in Peru, and the number of coal basins may be as few as four (Petersen, 1978) to as many as fifteen (Alvarado, 1980, p. 401). The most recent compilation of maps, locations, formations, ages, rank, and reserves for 230 occurrences of coal in Peru is provided by Carrascal and others (2000, p. 44). Even though Peru has abundant coal, most of Peru's electric power is provided from hydroelectric sources, and Peru imports coal from Colombia, Indonesia, and Venezuela for power generation in southern Peru (Bowen, 2001). 
The Goyllarisquizga Mine in northern Peru is perhaps the most well known occurrence because it supplied coking coal to the copper smelters at Cerro de Pasco. This coal mine was closed in the early 1970s, was then reopened, and then, due to declining production, closed again in the 1990s (Brooks and others, 2006a).

Because of global concern for mercury emissions related to coal-burning, the USGS initiated an inventory of the mercury and other trace element content of coal in the world market (Finkelman and others, 2001). Even though Peru is not one of the region's major coal-producing or coal-using nations, coal is available from several smaller mines such as Baños de Chimu, Cocobal, La Limeña, and La Victoria (Dunin-Borkowski, 1996, p. 148) and is used locally for calcining cement, cooking, or making coal briquettes. Analyses from these occurrences indicate that the mercury content of Peruvian coal is less than 1 part per million (ppm), and Peruvian coal does not appear to present any potential environmental or health problems (Brooks and others, 2006a).

\section{Geology and Mining}

Mercury is retorted from, or is found in association with, the sulfide mineral cinnabar. It is a scarce metal that is silvery and liquid at room temperature in elemental form. It averages $0.05 \mathrm{ppm}$ in the Earth's crust. Mercury's chemical and physical properties, isotopes, and thermodynamic properties are given in DeVito and Brooks (2005).

Also known as azogue (Arabic) or llimpi (Quechua) in Andean Latin America, mercury occurs as a native metal or can be produced by retorting cinnabar. The more common ore of mercury, cinnabar, is dark red and soft, and may be associated with low-sulfidation epithermal mineral deposits worldwide; this is a type of hydrothermal mineral occurrence with a specific suite of minerals that forms at depths of less than $1 \mathrm{~km}$ and at temperatures of less than $300^{\circ} \mathrm{C}$. Mercury ores may be found disseminated in finegrained or brecciated volcanic rocks near volcanic centers, fossil hot springs, and intrusive rocks and may be any age from Silurian to Tertiary (Cox and Singer, 1986, p. 178).

Cinnabar is commonly mined by underground or open-pit methods from depths of less than $350 \mathrm{~m}$. There are numerous mercury occurrences in Peru (Petersen, 1970, p. 55) and the most well known, the Santa Barbara Mine in Huancavelica, is now closed. Mercury miners at Huancavelica used the intensity of the color of the cinnabar, "... sangre seca, ley mas alta [if the ore is the color of dried blood, the grade is higher]," to indicate ore grade.

In general, mercury ores may contain from 0.1 to more than 2 percent mercury; however, most economic ores contain more than 1 percent mercury. The ore is crushed, screened, and then heated in a retort or furnace with limited ore beneficiation. Other specialized methods include leaching, dissolution, and electro-oxidation (Nowak and Singer, 1995, p. 232). Mercury occurrences, as cinnabar, are widespread and are known in Algeria, China, Italy, Kyrgyzstan, Mexico, Spain and the United States.

Since 1927, the common unit for measuring and pricing mercury has been the "flask," which was set to conform to the system used at Almaden, Spain (Meyers, 1951). One flask weighs $34.5 \mathrm{~kg}$, and $1 \mathrm{t}$ of mercury contains approximately 29 flasks. The flask itself is a screw-top, welded-steel container that is approximately the size of a 2-liter soft drink bottle. During the Spanish Colonial period, the Huancavelica mines produced over 48,000 t (1,470,000 flasks) of mercury with most of this coming from the Santa Barbara Mine (Yates and others, 1955, p. 11).

\section{Byproduct Production of Mercury}

In 2006, world mine production of mercury was 1,480 t, and China was the leading producer $(1,100 \mathrm{t}$ ) followed by Kyrgyzstan (250 t), Russia (50 t), and Tajikistan (30 t) (Brooks, 2007). However, mercury may also be produced as a byproduct from the processing of copper (tennantite-tetrahedrite), gold (amalgam), lead-zinc (sphalerite), and silver (kongsbergite) ores (Rytuba, 2003). Of these occurrences, 
most byproduct mercury is produced from epithermal gold-silver occurrences in a regional subduction setting, for example, in the western United States or the western part of South America.

At Barrick's Pierina gold mine, near Huaraz in northern Peru, and at Newmont's Yanacocha gold mine, near Cajamarca, also in northern Peru, the gold-silver ore, which also contains mercury, is milled and then leached with cyanide to remove the metals. In the zinc precipitation process (Merrill-Crowe process), mercury is also precipitated with the gold and silver, and some of these precipitates may contain in excess of 20 percent mercury (Washburn and Hill, 2003). A carbon-based extraction system is then used to recover the dissolved metals. The gold-silver-mercury amalgam, or Merrill-Crowe precipitate, is then sent to a large, on-site retort for step-heating, which will volatize and remove the mercury from the gold-silver ore. The volatized mercury cools, condenses, and then passes into a tank that is periodically tapped, and the mercury is drained into a $1 \mathrm{t}$ container. The container sits in a larger, water-filled pan that will trap any droplets of mercury that may splash during tapping. The 1-t container itself has a 2-to 3centimeter $(\mathrm{cm})$ layer of water inside that keeps the mercury from volatizing at ambient temperatures. The byproduct mercury is then transferred to flasks for export only to the United States and the gold-silver concentrate moves on for further treatment in-plant.

A number of strictly enforced health and safety measures are in place at the on-site retorts, which are separate from other mine operations. The mercury flasks are drop-tested for security and measured for standard dimensions. After the flasks are filled, the mercury may then be chemically tagged, and the flask caps are double-sealed. The filled flasks are placed in a larger container, which has also been drop tested for security (fig. 1). That container is then bolted shut before dedicated shipment to the port in Callao, Peru, for export to mercury recyclers in the United States for processing. Mercury will volatize at room temperatures (Putman, 1972, p. 513), therefore, 1-2 cm of water on the retort-room floor keeps any splashed mercury droplets from volatizing. Gold rings, cameras, pens, and other metallic items are not permitted in the retort area. Workers and visitors must sign in and out, wear rubber boots, and use protective, disposable clothing. Visitors and workers are chemically "sniffed" before leaving the building, and workers submit to periodic blood and urine testing.

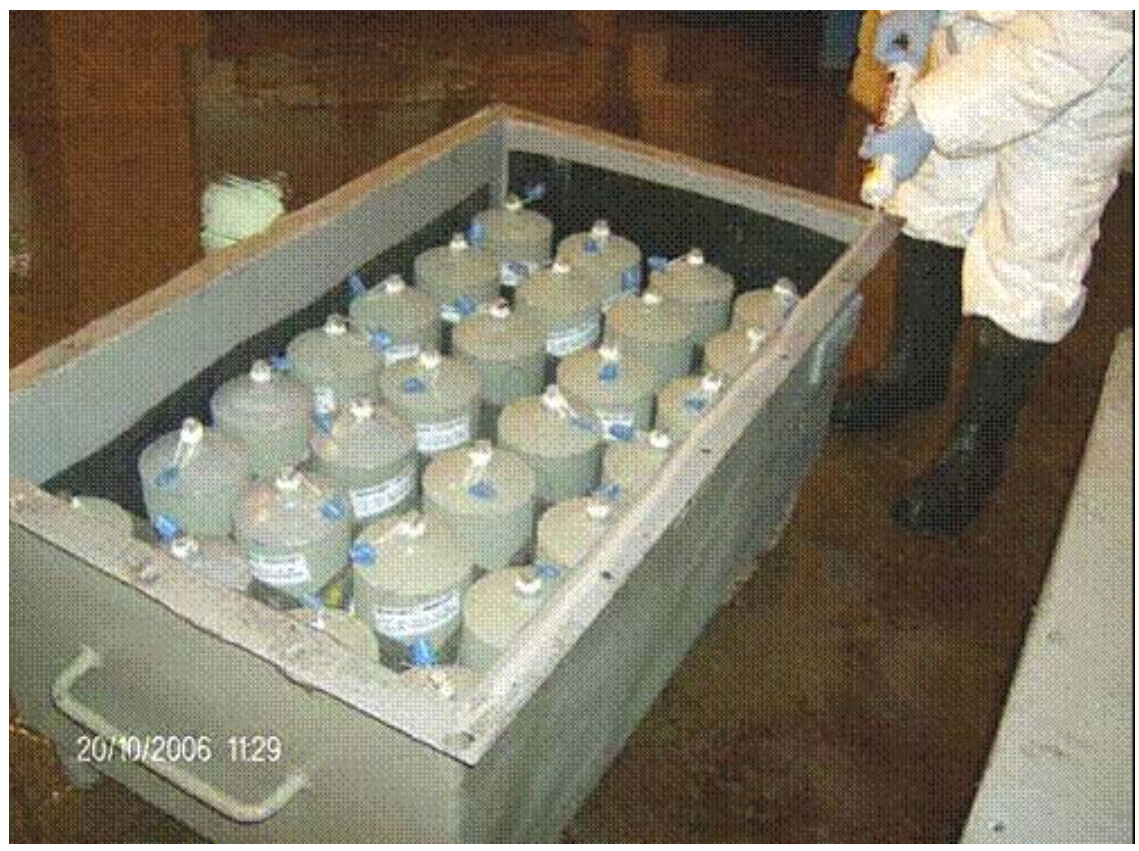

Figure 1. Security container with flasks of byproduct mercury before leaving Newmont Mining Corporation's Yanacocha mine, northern Peru. (Photograph permission of Newmont Mining Corporation) 
The major mining companies operating in Peru recognize the environmental and human health issues associated with byproduct production of mercury and therefore export their mercury to the United States for treatment and recycling. However, after the mercury is processed in the United States, it may then be resold in the international metals market for a variety of purposes. That carefully safeguarded shipment of byproduct mercury that originally came from Peru may then be shipped to warehouses or importers in Europe, South America, or other destinations for artisanal gold mining or a variety of industrial uses (Fialka, 2006).

Another solution to the byproduct mercury problem is chemical stabilization of the mercury using sulfur to make artificial cinnabar. In collaboration with the U.S. Department of Energy's Brookhaven National Laboratories, Minera Yanacocha S.R.L., is researching ways to chemically stabilize or otherwise encapsulate the mercury (Ron Bradburn, process manager, Minera Yanacocha, S.R.L., written commun., June 1, 2005).

Peru is an important exporter of byproduct mercury from its precious metals mines to the United States, and according to the U.S. Geological Survey (USGS), $22 \mathrm{t}$ (2006), $128 \mathrm{t}$ (2005), $0 \mathrm{t}$ (2004), $19 \mathrm{t}$ (2003), $0 \mathrm{t}$ (2002), $29 \mathrm{t}$ (2001), and $11 \mathrm{t}$ (2000) were exported to the United States for treatment and resale.

From 1994 to 2000, an average of 20 metric tons per year (t/yr) of byproduct mercury was produced by one mine in Peru, according to Peru's Corporación Financiera Internacional; however, the disposition of this mercury is unknown. Peruvian customs indicate that from 1993 to 2000, an average of $40 \mathrm{t} / \mathrm{yr}$ of mercury was imported for chlor-alkali production, medical uses, and artisanal gold mining (Carmen Mora Donayre, director, Ministerio de Industria, Turismo, y Negociones Commerciales Internacionales, written commun., September 6, 2001).

\section{Mercury Uses in Peru}

The chief uses of elemental mercury imported into Peru include artisanal gold mining, chlor-alkali production, and dental amalgam. Mercury imported for use in Peru may also be transshipped to other destinations in South America such as Colombia, Ecuador, or Guyana. Peru's domestic byproduct mercury is not used directly in Peru and is exported to the United States for processing and resale (Fialka, 2006).

\section{Overview of Artisanal Gold Mining}

Mercury has been used for artisanal gold mining in Peru at least since the time of the Moche (approximately 100 B.C.-A.D. 750), who lived along the northern coast of Peru (Larco Hoyle, 2001, p. 128). The widespread use of mercury for artisanal gold mining continues today in the Department of Piura in the northwest (Minas y Petroleo, 2006a); in southern coastal areas that include parts of the Departments of Ica, Arequipa, and Ayacucho (Canepa, 2005, p. 7); and the Departments of Puno and Madre de Dios in southeastern Peru (Kuramoto, 2001; Guerra, 2007). It is estimated that more than 200 t/yr of mercury are released annually through artisanal, or small-scale gold mining throughout Latin America (Viega, 1997).

In a review of all types of gold occurrences in Peru, Noble and Vidal (1994) outlined three areas of alluvial or artisanal gold production; these were, from north to south, Rio Huallaga, Maranon, and Madre de Dios; however, no production data were given. From 1990-1999, in increasing order of production, Costa Norte (La Libertad, Pataz), Costa Sur (Arequipa, Ica), Puno, and Madre de Dios produced a total of approximately $20 \mathrm{t} / \mathrm{yr}$ of gold, according to the Ministerio de Energía y Minas.

In 2001, approximately 17 percent of Peru's total gold production was from artisanal production of gold from vein and alluvial occurrences, and of that total, 70 percent was from Madre de Dios (Kuramoto, 2001). Other important areas include the Department of Puno, the southern coastal area, and the Department of La Libertad, and now, Piura. In 2004, artisanal gold mining accounted for 9 percent (14.8 t) of the gold produced in Peru (Gurmendi, 2004), and in 2005, the Ministry of Energy and Mines indicated that a minimum of 12,000 people working in the country's artisanal gold mining sector produced $15.8 \mathrm{t}$ of gold (El Minero Artesanal, 2007). 
The simplest method of amalgamation is with a wooden gold pan (batea), mercury, and the goldbearing sediments. Either alluvial sources, or vein occurrences that have been processed, are washed directly until only the heavy minerals, including gold and "black sand" remain. Mercury is then added which amalgamates with only the gold. The gold-mercury amalgam may then be removed for further treatment, and the remaining material, which may still contain some gold, is treated with cyanide. The quality of the mercury, whether virgin (preferred) or recycled, is an important factor in gold recovery. At alluvial or placer gold occurrences, the sediments may be collected directly from the streams, or in some mining operations, front-end loaders may dump the sediments in grizzlies, and the gold-bearing sediments are then treated by hand once the larger stones are removed.

In vein or hard-rock mining areas, meter-sized crushing stones (quimbaletes) are used. The goldbearing material is crushed by rocking the quimbalete, then washed, and the remaining muddy sediment is washed again to remove the light minerals. Mercury is added to amalgamate with the gold. The density of the amalgam causes it to sink to the bottom of the slurry. In the third method, gold-bearing material is put into a ball mill (molino á bolas), mercury is added to amalgamate with the gold, and the light materials are removed by washing. In all of these examples, the mercury-gold amalgam is then burned either in the open-air or in a retort, the mercury is partially to completely volatized, and the gold remains. If the openair system is used, or if the mercury is retorted indoors, then mercury may be released directly to the surroundings (fig. 2). If a sealable retort is used, then a small amount of mercury may be captured from a condenser tube on the side of the retort (fig. 3). Regardless, significant mercury losses take place.

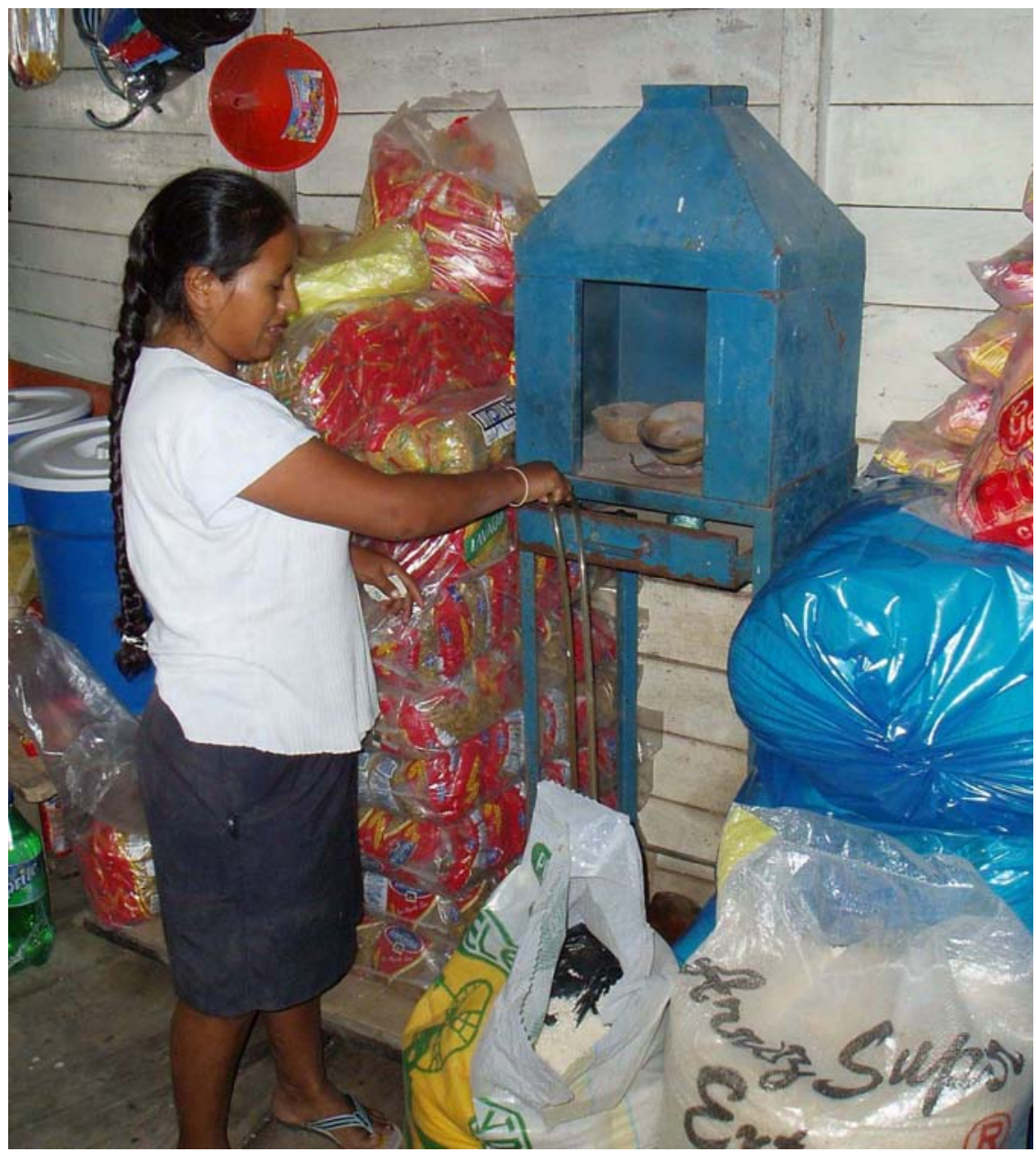

Figure 2. Unvented mercury retort for gold processing in a grocery store in Inambari, Madre de Dios, Peru (Photograph by William E. Brooks) 


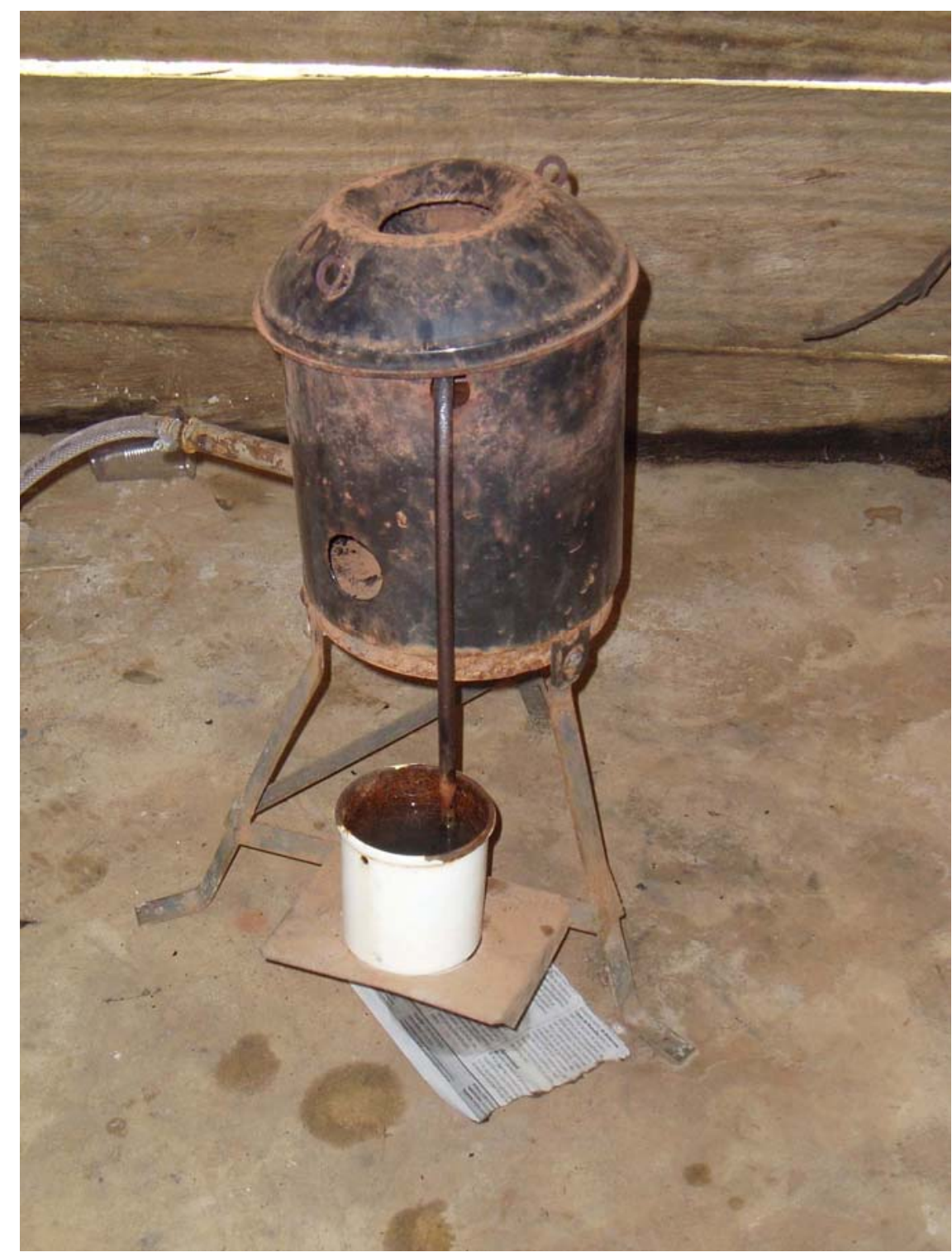

Figure 3. Sealable mercury retort at Mina Cabecera Santa Ynes, Huepethue, Madre de Dios, Peru. Tube on side helps to capture some of the volatized mercury fumes. (Photograph by William E. Brooks)

Each quimbalete operation will use $1-2 \mathrm{~kg}$ of mercury daily, and $800 \mathrm{~g}$ of mercury may be recovered with a loss of 200 to $1,200 \mathrm{~g}$ of mercury. Treatment of the amalgam in a closed retort results in approximately 10 percent recovery of the mercury with a 90 percent loss of mercury as toxic fumes when the gold is burned (Canepa, 2005, p. 50). The 10 percent that is recovered by this method must then be cleaned before reuse. At the gold-buying shops in the mining towns, the metal may once again be burned with a gas torch to remove any remaining impurities or mercury. Usually, but not always, there is a chimney from the retort in the gold shop that releases any fumes from this process to the outside (fig. 4A, B). Even though most chimneys vent to the outside, approximately 50 percent of the mercury released precipitates in the area surrounding the place where it is burned, and high levels of mercury have been found in the blood of people who live in or above the gold shops (fig. 2) (Kuramoto, 2001). 

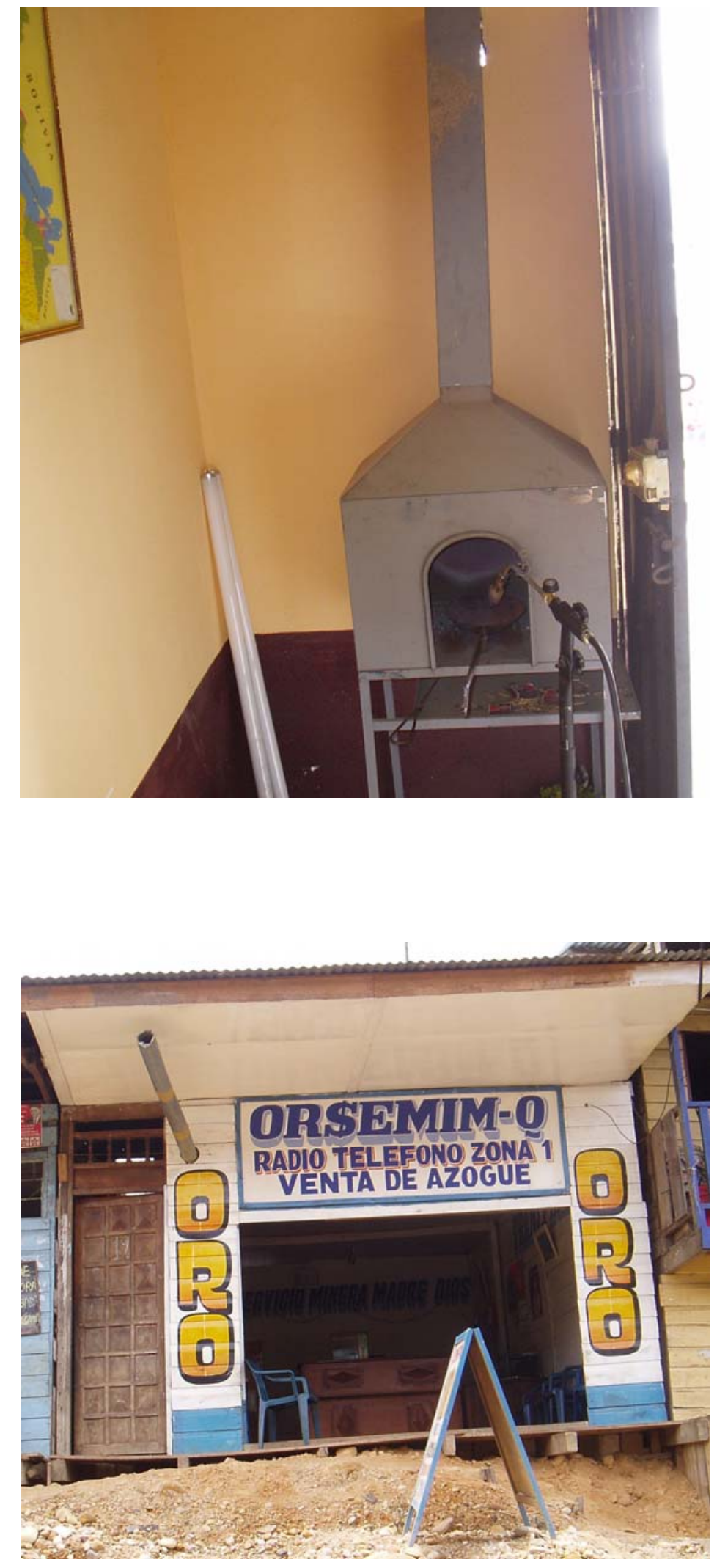

Figure 4A. Mercury retort with chimney, with B) chimney from inside gold shop to vent mercury fumes outside, Huepethue, Madre de Dios, Peru. (Photographs by William E. Brooks) 
At the Huepethue mine site, a $1 \mathrm{~g}$ sample of amalgam, before retorting or burning, contained 312,000 ppm mercury. After the two-stage process of retorting and burning with the gas torch, a $1 \mathrm{~g}$ sample of gold contained 822 ppm mercury.

Then, at the gold shop, a final burning step helps the dealer gauge the purity of the gold, set a price and, most importantly, at all times the gold is visible to the dealer and to the miner. After the gold cools, the dealer weighs the gold and pays the miner. Because of safety and the threat of being robbed, only partial payment may go directly to the miner, and the dealer will transfer the balance of the payment to a bank or a gold office in the miner's hometown. The dore from the gold shop is then collected and transported to Lima for further processing and some mercury may be removed before the dore is sent to the United States for further refining and parting of the gold and silver (S. Gutierrez, general manager, Procesadora Sudamericana, oral commun., February 15, 2007).

The amount of artisanal gold produced is an important factor in estimating mercury use. To produce a given quantity of gold, two to three times as much mercury is used (Roskill Information Services, Ltd., 1990, p. 105; Sausa, 2007); therefore, $32 \mathrm{t}$ of mercury, or more, may have been used to produce the $16 \mathrm{t}$ of gold from Peru's artisanal mining sector in 2005. The price of the mercury is based on its origin; that is, virgin mercury from, or perceived to be from Almaden, Spain, is more costly. Recycled mercury, typically from the United States, is also used, but virgin Spanish mercury is preferred because miners believe that it gives better gold recovery. Some recycled mercury may be packaged in such a way as to imply Spanish origin and therefore receive a better price for the mercury. There is no information on the recovery rate of artisanal gold using virgin or recycled mercury. Regardless, after the mercury is used, very little is recovered or recycled. However, the mercury that is recovered may be cleaned using a variety of methods that include: electricity from 12-volt batteries; lemon juice; paper towels; soap; or toilet paper. After Spanish mercury, recycled mercury is a second choice for gold amalgamation; however, most of the mercury used for gold amalgamation, regardless of its origin, is released as mercury fumes during retorting or is otherwise lost to the environment and is not recycled.

In some cases, the miner will sell his mercury-gold concentrate obtained from the quimbalete or ball mill directly to a dealer. Virgin mercury is preferred for presumably better gold recovery; however, some dealers may sell low quality or recycled mercury to the miner, which will then result in incomplete recovery of the gold from the concentrate. The tailings from this transaction will then be sold and treated with cyanide for further gold recovery, and the miner receives no profit from the gold recovered from this later process.

Because of mercury losses, human health, and environmental concerns, and the reluctance of miners to let their gold leave their sight during retorting, communal, miner-operated retorts have been established as part of an international environmental program between Switzerland and Peru. Since 1993, the Swiss Agency for Development has been involved with environmental projects related to mining in Bolivia, Ecuador, and Peru. Even though hand-held retorts are relatively inexpensive, most miners do not like and rarely use them. Some miners think that retorts may turn the gold green, which will result in a lower price, or that the process is slower than traditional methods (del Carmen Piazza, 2001).

Because of these concerns, miner-run retorts with a traditional open-faced oven, so that the miner can see his gold during every step of retorting, have been built. Condenser tubes are installed and the mercury can then be recovered, recycled, and resold locally. Approximately 120 kilograms per year (kg/yr) of mercury can then be reused (Hruschka, 2007).

The Peruvian environmental organization, Proyecto GAMA (Gestíon Ambiental en la Minería Artesenal) and the Ministerio de Energía y Minas del Peru has also tried to reduce mercury releases by providing free retorts and reactivadores de mercurio [mercury reactivators]. The reactivador de mercurio is a small rubber cup with a cathode and anode that will attach to a 12-volt battery (fig. 5). The used mercury is placed in the rubber cup with $2-3 \mathrm{~cm}$ of water and the mercury may be cleaned by passing the electricity through the mercury and the mercury, now recycled, can then be reused. From 1996 to 2000, approximately 1,600 reactivadores were distributed in artisanal gold mining areas (Medina Cruz, 2001). 


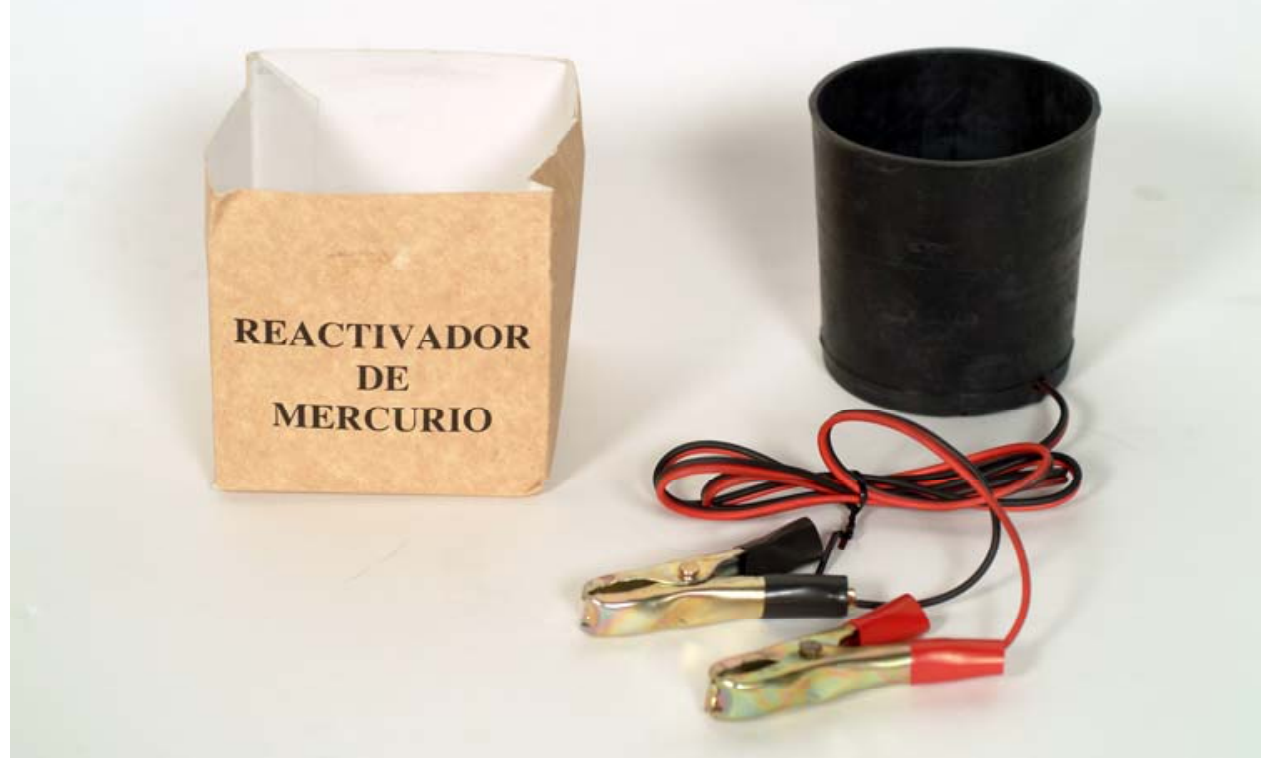

Figure 5. Mercury reactivator for cleaning and recycling mercury by using electricity from a 12 volt battery. (Photograph by William E. Brooks)

Environmental contamination caused by mercury releases related to artisanal gold mining has been addressed by government and other agencies in Peru. Mercury losses in Madre de Dios were researched by Galloso and others (1996) and the Ministerio de Energía y Minas (2005) has published a guide to the use of mercury that also addresses handling and transportation issues. As a part of the Swiss environmental program, designs for community retorts, mitigation of mercury releases, and health effects are described in a guidebook distributed in artisanal mining areas by Adrianzen (2005). Newspaper articles address governmental concern about widespread contamination caused by mercury used for artisanal gold mining (Diario Gestíon, 2007; Guerra, 2007).

From Piura, in the northwest, to Madre de Dios, in the southeast, artisanal gold mining is an important economic activity; however, there are health risks involved with using mercury and from the toxic fumes released from burning the gold-mercury amalgam. Children working in the artisanal mining areas are exposed to mercury on a daily basis, and the damage to their health and mental development is irreversible (Sausa, 2007). There are a minimum of 50,000 workers, many of whom are children, and the combination of malnutrition, exposure to mercury, time devoted to work, and, in some cases, altitude, are key factors in understanding why there is a high proportion of children with intellectual developmental difficulties in the artisanal mining communities (del Carmen Piazza, 2001).

Artisanal gold mining is a global activity, the processes are similar, and mercury is widely used. Therefore, The Global Mercury Project has published "Protocols for Environmental and Health Assessment of Mercury Released by Artisanal and Small-Scale Gold Miners" (Viega and Baker, 2004) and a "Manual for Training Artisanal and Small Scale Gold Miners" (Viega and others, 2006). The purpose of these books is to introduce cleaner and healthier artisanal gold mining and extraction technology. Chapters discuss gold ores, crushing, gravity methods, classical and home made retorts, amalgamation, use of cyanide, and the environmental and health effects of mercury exposure.

\section{Piura}

Even though the Department of Piura, in northwestern Peru, is considered one of the best locations for exploration and mining in Peru, it did not figure into 2005 Ministry of Energy and Mining statistics for 
gold production nor did Kuramoto (2001) include Piura in her compilation of important artisanal gold producing regions. In the 1990s mining investments began flowing into Peru and one of these projects was Tambogrande in Piura. The Tambogrande project was different because it brought the possibility of largescale, open-pit mining, which had previously only taken place in Andean Peru, to an established agricultural region. Conflict over the potential environmental affects ensued and the mining company left in 2003 (Wilson, 2004; De Echave, 2005; Guerra, 2007). However, conflict between artisanal mining and agriculture was just beginning.

Since 2001, artisanal mining has been growing in Piura. Some of the more well known locations include San Lorenzo, Las Lomas, and El Chira; however, there are many more. There are a minimum of 4,000 artisanal miners in the area and the regional government of Piura has established a census commission to establish the number of workers and families involved in mining (El Peruano, 2007).

Gold is worked mainly using quimbaletes and ball-mills - both processes use mercury. Approximately $4 \mathrm{~kg}$ of gold may be obtained from every $100 \mathrm{t}$ of rock that is crushed using the quimbaletes and each kilogram may be worth as much as \$21,000 (Obregon Rossi, 2007). The mercury comes either from Trujillo or from nearby Ecuador and sells for $\$ 60$ to $\$ 75$ (S/. 180 to 225) per kilogram. There is no recovery of the mercury, and the gold is burned in the open without the use of retorts (Minas $y$ Petroleo, 2006a, p. 10).

Mining methods also include the use of cyanide and dynamite for blasting. Gold-bearing waste rock from the ball-mines and quimbaletes is purchased and transported for treatment with cyanide at cyanidation pits 20 to $40 \mathrm{~km}$ northwest of Tambogrande, or as far south as Nazca, for further gold recovery. The use of cyanide, mercury, and zinc and the fact that waste rock from the quimbaletes is left in the open, or put almost anywhere, and may drain these metals directly into the groundwater is a cause of intense concern to the agricultural community in Piura. Uncontrolled artisanal mining and the widespread use of mercury and cyanide has contaminated the rivers in the region, the San Lorenzo reservoir, and the water in the agricultural areas of Las Lomas and Tambogrande. Neither the miners nor the many underage children working in the region use any sort of protection when working with these toxic materials (Obregon Rossi, 2007).

Approximately $120 \mathrm{t}$ of waste rock from the quimbaletes may be transported daily for processing with cyanide and from those $120 \mathrm{t}$, another $2.4 \mathrm{~kg}$ of gold may be obtained daily, with a yearly yield of $864 \mathrm{~kg}$ of gold (La Hora, 2007a; La Hora, 2007b). There are no data on the amount of gold recovered from the less efficient, mercury-only methods. There are locations where it is possible to obtain $5 \mathrm{~g}$ gold from a $30 \mathrm{~kg}$ load of rock and a gram of gold may be worth approximately $\$ 20$ (S/. 45-60) to the mine owners. Laborers at the quimbaletes and at the mines may receive approximately $\$ 8$ (S/. 20-25) per day compared with approximately $\$ 2.50$ (S/. 8) for a day's work in the agricultural sector, and one former agricultural worker indicated that his daily wages had quadrupled.

\section{La Libertad}

Pataz-Artisanal mining in the Department of La Libertad is mainly near Pataz which is approximately $350 \mathrm{~km}$ east of Trujillo in northern Peru. Since pre-European contact, this has been one of Peru's major gold producing areas. Most gold is extracted from gold-quartz-pyrite veins that crop out for a distance of approximately $70 \mathrm{~km}$ and are associated with the Pataz batholith (Schreiber and others, 1990, p. 1328; Noble and Vidal, 1994). However, the Pataz gold mining area was not visited because it is within an area outlined by the U.S. Embassy as restricted because of coca production.

At Pataz, the gold-quartz-pyrite veins are of primary interest and adits follow the high-grade zones. The adits are dangerous (Warren Church, anthropologist, Columbia State University, written commun., December 14, 2006). Ore is extracted using hand drills and sledgehammers. Beneficiation of the ore includes sledgehammers and quimbaletes. Mercury is added to the crushed and washed material and then the amalgam is squeezed through a cloth and some mercury is recovered for reuse. The amalgam is then burned to remove any remaining mercury and the gold is then sold. The alluvial deposits, which are of less importance, are mainly along the Rio Maranon and Rio Cajas where the gold-bearing gravels shed from 
the batholith are worked with shovels, gold pans, and mercury (Kuramoto, 2001). Cyanide and carbon treatment is also being used to recover gold in this area.

Trujillo (site visit) - In 1998, La Libertad was fourth in artisanal gold production, which was estimated to be $190 \mathrm{~kg}$ (Kuramoto, 2001). In Trujillo, at Inversiones Mineras Victoria S.A.C., the "El Español" brand of mercury is sold along with cyanide, zinc powder, and other mining supplies such as boots, dust masks, gloves, and hard-hats (Miguel Angel Rodriguez, owner, Jr. Bolivar 717, written commun., February 5, 2007). Many gold shops are nearby; however, these do not sell mercury or mining supplies. From gold production data, it is inferred that less than $1 \mathrm{t}$ of mercury was released through artisanal mining in 1998. There were approximately 700 miners working in the Pataz area in 1998 (Kuramoto, 2001) and 11 years was the minimum age for children to work in the mines (Warren Church, anthropologist, Columbia State University, written commun., December 14, 2006); however, Juan Valdivia, Minister of Energy and Mines, indicates that children as young as 4-6 years are used as cheap labor or "helpers" in the broader artisanal mining sector (Guerra, 2007).

\section{Madre de Dios}

Huepethue (site visit)—Madre de Dios produces approximately 70 percent of Peru's artisanal gold (Kuramoto, 2001). At Huepethue, one of the most important artisanal mining centers in the jungle in the Department of Madre de Dios, mining takes place at an area locally referred to as "Las Quebradas." Other nearby mining areas include: Caychihue, Puerto Carlos, Puquiri, Laberinto, and other unnamed occurrences. Huepethue, which may or may not appear on maps, is approximately 15 hours by hazardous road, boat, and stream crossings from Cusco. When available, there is seasonal air service from Cusco to Huepethue.

Gold extraction methods used in Madre de Dios include channeling, dragging, sluicing, use of boats with suction hoses, and dredges. Bateas (gold pans) are used and one of the simpler methods used at Huepethue is the "balde" or pig-tail bucket. These buckets are filled with sediment and then the sediment is washed, sometimes by foot to concentrate the gold at the bottom of the bucket. Light materials are floated, gravel is removed by hand, and then mercury is added. "Chupaderas" or boats with divers using suction hoses are used in the rivers, especially at Laberinto. The gold-bearing sediments are brought to the surface using the suction hoses and mercury is added to the sediments to recover the gold. These artisanal methods are widely used; however, the presence and use of numerous dump trucks, excavators, and frontend loaders all indicate substantial investment in the area.

Sediments collected by the methods described above all rely first on gravity to separate gravel and light minerals from the nuggets, finer gold particles, and heavy mineral sands. The nuggets are extracted by hand and the finer gold particles are recovered by amalgamation. Because of the widespread use of mercury and environmental concerns, Galloso and others (1996) studied the dispersion of mercury in Rio Madre de Dios as well as studies near Caychihue, Puerto Carlos, Puquiri, and Huepethue. Madre de Dios was also included in a regional study of artisanal mining, environmental impact, occupational health, and child labor by Kuramoto (2001).

At Huepethue, gold is found in placer deposits that may be from 20 to $70 \mathrm{~m}$ thick in an area that may be 25 square kilometers or larger with 7,000 to 10,000 miners. The area has been mined for gold since Spanish Colonial time; however, it saw a resurgence of activity in 1977. At the site visit to Mina Cabecera Santa Ynes, trucks dumped gold-bearing sediments in a large grizzly at the top of a hill, gravels were removed, and the sediment was washed downhill in a ziz-zag sluice lined with carpet (fig. 6A, B). The carpets were recovered from the sluices and the gold was washed into a muddy settling pit from which the gold-bearing sediment was recovered. Mercury was then added, mixed by hand with the sediment, the amalgam was recovered, and was then placed into a small retort in a cabin (fig. 4A). The retort was bolted shut and the amalgam was heated for approximately 30 minutes. A small tube on the side of the retort condensed some of the mercury fumes in a water-filled cup for later cleaning and reuse. All mine staff left the cabin and it was locked while retorting took place; however, dark smoke indicated the release of mercury fumes. After the smoke cleared, the retort was opened and the smudgy brown gold 
ingot was recovered. This ingot was allowed to cool, then broken with a hammer and burned again [refogado] to remove any remaining mercury (fig. 7A, B). The broken fragments are burned with a gas torch until glowing and, upon cooling, the beauty and attraction of the precious metal is compelling-this is an important, hands-on step because the price that the miner will be paid is based on the color of the gold, and the miner can then judge the quality of his metallurgy, the purity of the gold, and the price that he will receive (fig. 7B).
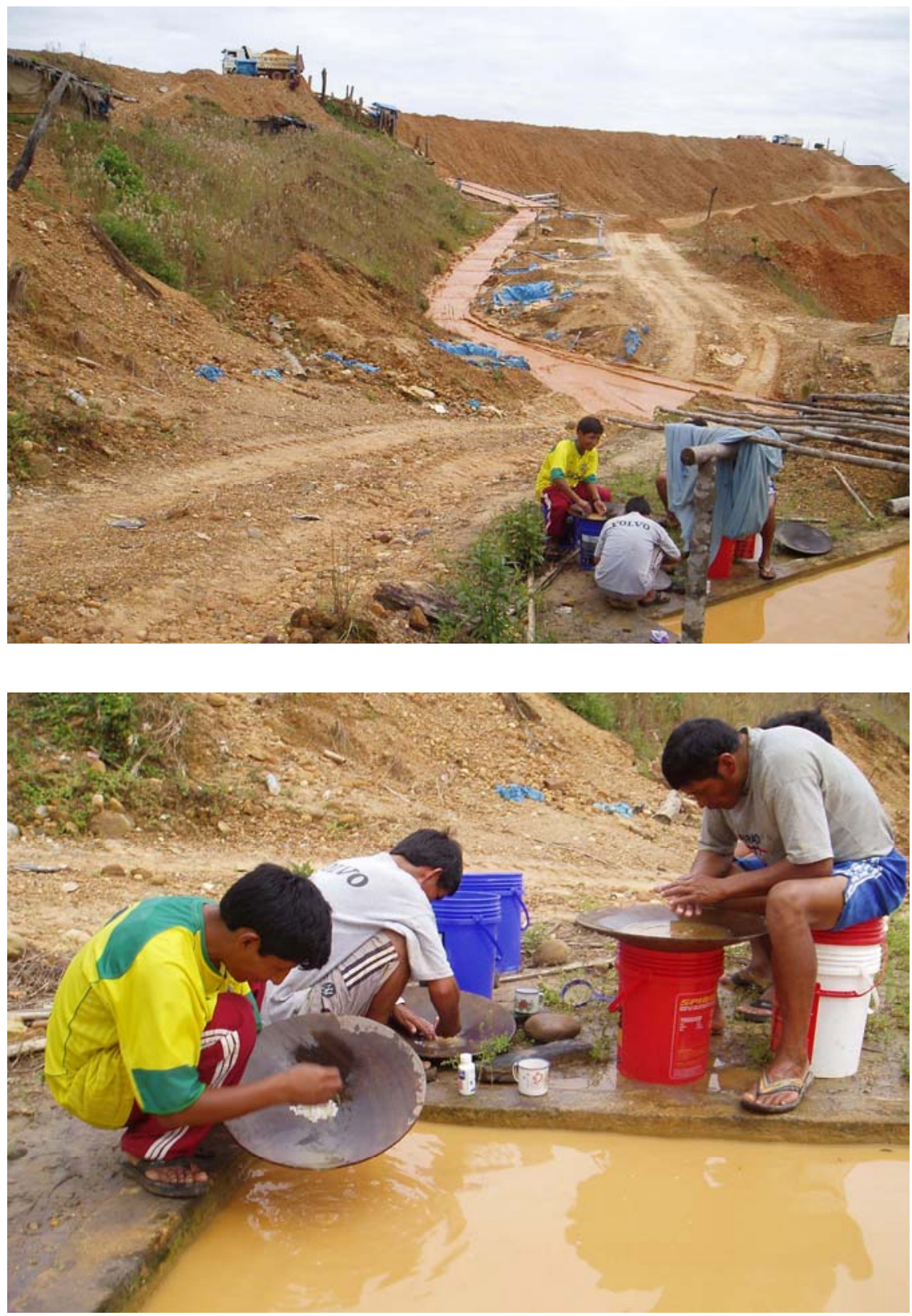

Figure 6A) Sluice and b) silvery, mercury-gold amalgam in gold pan (batea) in foreground at Mina Cabecera Santa Ynes, Huepethue, Madre de Dios, Peru. (Photographs by William E. Brooks) 

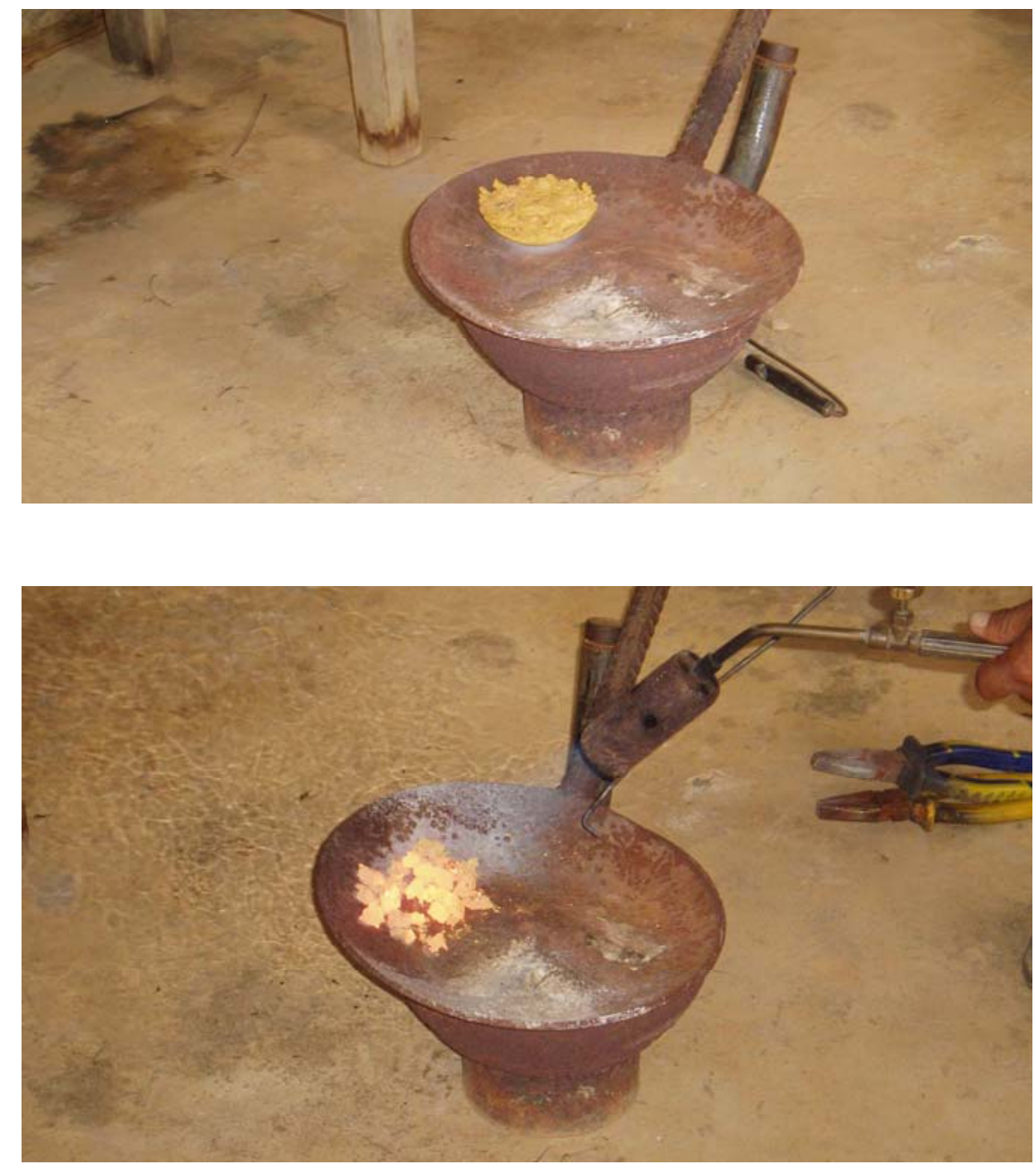

Figure 7A. Gold immediately after being removed from the retort and 7B gold after being burned (refogado) to remove any mercury and improve the aesthetic appearance of the gold, Mina Cabecera Santa Ynes, Huepethue, Madre de Dios, Peru. (Photographs by William E. Brooks)

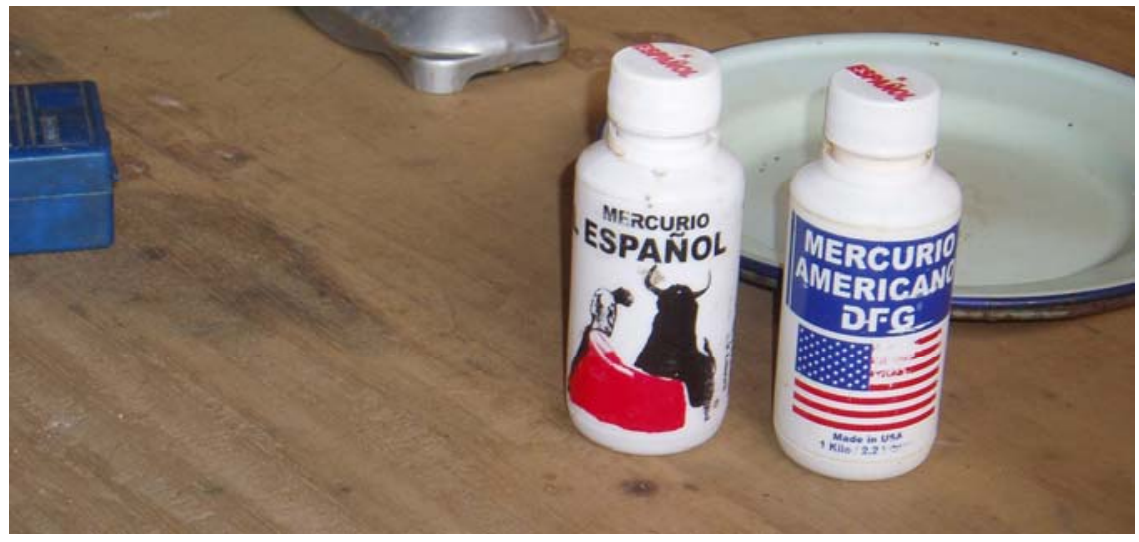

Figure 8. Widely used “El Español” brand of recycled mercury. (Photograph by William E. Brooks) 
Mercury used in gold processing at Huepethue was bought locally and was labeled either "American Mercury" or "El Español" and prices varied between $\$ 50$ and $\$ 60$ (S/.150-180) per 1-kg bottle (fig. 8). Very little mercury was recovered in the cup at the retort. The amount of mercury used daily or monthly is dependant on ore grade; however, the miners indicated that they might use $500 \mathrm{~g}$ to $2 \mathrm{~kg}$ weekly at this mine alone.

\section{Puno}

The Department of Puno is in mountainous southeastern Peru near the border with Bolivia. Artisanal exploitation of gold-bearing quartz veins at 5,000 $\mathrm{m}$ in the Ananea-La Rinconada region of Puno was first described by Raimondi (1878). The gold-bearing quartz was crushed using quimbaletes and the ore was concentrated in bateas using glacial meltwater, a style used since pre-European contact (Petersen, 1970, p. 121).

Puno is the second most important artisanal mining area in Peru, with 17 percent of Peru's artisanal gold production, and Kuramoto (2001) estimates its production at $2.5 \mathrm{t} / \mathrm{yr}$. However, Juan Valdivia, Minister of Energy and Mines, estimates that the San Antonio de Poto region of Puno, which includes Ananea, may produce as much as $50 \mathrm{t} / \mathrm{yr}$ of gold, mainly because of lack of controls in the area (Guerra, 2007). Puno is a center of artisanal mining and is also the location of a new open pit gold mine, Mina Arasi, which is projected to produce 4.5 t/yr (Minas y Petroleo, 2006b, p. 6).

Juliaca is the nearest town and is approximately 4 to 5 hours by rural, unsurfaced road from the mining areas. Artisanal gold mining, which dates back to the Colonial period, is especially difficult because of high altitude $(5,000 \mathrm{~m})$ and cold. Anywhere from 7,500 to 30,000 people live in the area, and dwellings are made of adobe, brick, and stone with corrugated roofs. Streets quickly turn to mud in the rain or snow, and there is no infrastructure for trash removal. Mining takes place in the Rio Ramis watershed, and the combination of mercury from mining activities and contamination from trash dumped in open areas contributes to concern for human health and water quality in downstream areas. After periods of high runoff, communities downstream indicate that they have underweight cattle and that children do not want to eat, are sick, and frequently vomit. In 2000, the University of Montana and the Universidad Nacional del Altiplano-Puno (Peru) were awarded a grant from the U.S. Department of State to initiate environmental studies related to mining and metal contamination in the Rio Ramis watershed. One of the objectives of the study was to assess metals pollution, specifically mercury, in Lake Titicaca owing to artisanal mining upstream. Analyses of water and soil samples indicated a high level of mercury contamination, and approximately 27 percent of the pejerrey and 75 percent of the carachi (important local food fish) from Lake Titicaca exceeded the fish tissue-based water quality criterion of 0.30 milligrams (mg) (Gammons and others, 2006, p. 637).

Site visits were made to Ananea and La Rinconada-Cerro Lunar de Oro; however, other nearby mining areas include Ancoccala, Carabaya La Aurifera, Lampa, Masiapo, San Antonio del Oro, and Yanahuaya.

\section{Ananea}

At Ananea, gold is obtained from 10-m thick, or more, glacial-derived alluvial deposits using highpressure monitors, sluices, riffle boxes, and panning. There are some tunnels and shafts where mining is accomplished using shovels and wheelbarrows. Front-end loaders are also used, some of which work 24 hours. The front-end loaders and other heavy machinery indicate a substantial investment in gold mining in the region. At various times, the miners have been organized under the government agency Centromin and also as Minero Peru, Minería Los Andes, or Corporación Minera Ananea.

The amalgam from Ananea and La Rinconada-Cerro Lunar artisanal mining sites is brought to the gold shops in Ananea, where it is burned and the mercury fumes are vented to the outside of the shop. There is no recovery or recycling of the mercury in the field or in the gold shops. The gold price is fixed 
daily depending on prices obtained on the Internet from New York or London. One local newspaper, "El Minero Artesanal" carries a chart with 30-day New York and London gold prices. Therefore, the gold price paid is a function of gold prices from the Internet, depending on the source of the gold, and a percentage for the dealer (for example, Ananea gold has silver and is generally 92.6 percent gold; however, Rinconada gold is typically 95 percent gold). The dore, approximately 20 to $25 \mathrm{~kg}$ per month, goes to Juliaca and from there, to Lima (H. Llacsa Bustinea, gold dealer, Ananea, oral commun., February 18, 2007).

At Ananea, the "El Español" brand of mercury sells for $\$ 40 / \mathrm{kg}$ (S/. 120) and another brand “American Mercury" sells for \$30/kg (S/. 100). Another brand was available, also for \$30; however, the bottle only carried the name "Corporación Reggiper, S.A."

\section{La Rinconada-Cerro Lunar de Oro}

These two adjacent artisanal mining communities are very near Ananea. Elevation here is approximately $5,000 \mathrm{~m}$ and the towns are located at the terminus of a glacier that also supplies water to the communities. The local Civil Defense Agency of Puno has recommended evacuation of the 3,000 or more miners in the area because of the possibility of hazards such as glacial release and landslides (El Comercio, 2006).

Gold is hosted in subhorizontal, 2 to $40 \mathrm{~cm}$ quartz veins that contain gold, pyrite, galena, tetrahedrite, and other minerals (Kuramoto, 2001). Adits and small tunnels follow the quartz veins, and the ore is extracted using picks, explosives, and sometimes, compressors. The ore is crushed and ground using quimbaletes, and it is at this step that mercury is added. There are approximately 1,000 quimbaletes in use, gold recovery is low, and mercury losses are high. Approximately $500 \mathrm{~g}$ of mercury are used to recover 10 to $20 \mathrm{~g}$ of gold. The mercury-gold amalgam is squeezed through a cloth in order to recover some of the mercury, which is then cleaned with cotton or toilet paper. The amalgam is then burned either in the homes of the miners or is taken to the gold shops in Ananea for burning and sale.

\section{Chlor-Alkali Production}

Quimpac S.A. is the sole producer of chlorine, caustic soda, and related products in Peru. These materials are used to bleach newspapers, for swimming pools, medicine, and other industrial uses. Quimpac production units are located in Callao, Huacho, Paramonga, and Otuma, with headquarters in Callao (Quimpac S.A., 2005). Mercury cell technology (DeNora 14H3/14TGL) is used by Quimpac with installed capacity of $45 \mathrm{t} / \mathrm{yr}$ of $\mathrm{NaOH}$ (Nelson Felipe, spokesman, Clorosur, written commun., December 6, 2004). In 1989, Roskill Information Services Ltd., (1990, p. 70) indicated that total mercury-cell capacity for Peru was $74 \mathrm{t}$. However, the current mercury capacity of the cells at the Quimpac facilities was not available (Isias Flit, advisor, Quimpac S.A., oral commun., February 14, 2007). During 2006, data from Peruvian customs indicate that approximately $2 \mathrm{t}$ of replacement mercury were purchased from suppliers in Spain. And, as of February 2007, there were no immediate plans to change to non-mercury chlor-alkali production.

\section{Dental Amalgam}

Dentists have used amalgam, which contains mercury and other metals, since 1833 (Talbot, 1882). Modern amalgam contains mercury (50 percent), silver (34 to 38 percent), tin (12 to 14 percent), copper (1 to 2 percent) and zinc (0 to 1 percent) (Davis, 2003). Amalgam fillings may last from 2 to 20 years, depending on the size of the filling (Dr. John Mercantini, dentist, Reston, Va., oral commun., December 12, 2004). In the United States, amalgam is sold in pre-measured capsules that are opened in the dentist's office just before use, and the American Dental Association discourages the use of bulk mercury (American Dental Association, 2006). Approximately $30 \mathrm{t} / \mathrm{yr}$ of mercury is used in the United States and 
used or discarded amalgam from collection devices in dental offices may be processed to recover the mercury and the silver (Lawrence, 1995). There are no data on the amount of mercury that is recycled from dental amalgam in the United States.

Site visits were made to dental supply stores in Lima, a dental clinic at the Universidad Cayetano Heredia in Lima, and to a dental office in Trujillo. Bulk mercury in 100-g plastic bottles is sold in the dental supply stores in the 200 block of Avenida Emancipación in Lima. Several gold shops are nearby. Mercury sold in the dental supply shops is triple-distilled, has a label indicating that it has U.S. Food and Drug Administration approval, is imported from the United States, and distributed by a Peruvian importer. The cost is approximately $\$ 7$ (S/. 22) for the 100-g bottle, and no professional documentation is needed for purchase. The other metallic components for making dental amalgam are sold separately as a powder so that the dentist may make a custom amalgam at the dental office. A visit to other dental supply shops indicated that no chairside traps are sold with which to recover the discarded silver-mercury amalgam.

At the Universidad Cayetano Heredia, dentists use either bulk mercury or pre-measured amalgam capsules that are imported from Australia. There is no system to capture the unused or discarded silvermercury amalgam. The discarded amalgam is either put into the trash or goes directly into the local sewage system from the chairside spitoon provided for the patient. In general, the use of amalgam, which is typically dark, is declining, and composite fillings that have a more natural color are preferred (Dra. Allison Chavez and Dr. Elar Ventura, dentists, oral commun., Clinica Dental de la Universidad Cayetano Heredia, Lima, January 30, 2007).

At the dental clinic in Trujillo, bulk mercury is commonly hand-mixed with silver-bearing powder for making amalgam. These fillings are inexpensive and generally cost $\$ 10$; however, for aesthetic reasons given above, amalgam use is declining and most patients prefer composite restorations (Dr. Alex Rodriguez, dentist, Primavera Centro Odontológico, Trujillo, oral comm., February 5, 2007). Dr. Rodriguez was especially interested in this study because he had recently finished his thesis research on "The influence of low-temperature polishing on high-copper dental amalgam" at the Universidad Nacional de Trujillo.

\section{Other Uses and Disposition of Imported Mercury-Containing Products}

Mercury-containing products include batteries, computers and electronics, fluorescent lamps, and thermometers. Children's light-up toys and some toothbrushes may contain batteries as well, but specific data on the large quantity of toy and other battery-containing imports were not available. None of the mercury contained in these products is recycled and may ultimately be released to the environment.

\section{Batteries}

There are many sizes, shapes, and varieties of everyday-use batteries, and virtually all batteries contain some mercury. Mercury oxide is used in varying amounts, especially in "button" batteries; however, alkaline batteries generally have the lowest mercury content. Cadmium-mercury batteries have been widely used in watches, calculators, cameras, and hearing aids (Battery-Index, 2003; Mercury in Batteries, 2004). In the United States in 2004, mercury batteries imported from China were used in approximately 17 million light-up toys distributed in cereal boxes that were clearly marked "battery in toy contains mercury" (Spitzer, 2004). In Peru, inexpensive "button" batteries that were sometimes swallowed by children were blamed for blindness and other health problems (El Comercio, 2002; 2003).

"Button" batteries from China and Japan are routinely sold in multi-battery packs in stores, and replacement batteries for watches and hearing aids are sold on many street corners in Lima, Trujillo, and elsewhere and the used batteries are thrown into the trash. Recently, Supermercados Wong, S.A., a large supermarket chain in Lima, has placed battery recycling canisters outside its stores. At Colegio Roosevelt, a private high school in Lima, as part of an environmental studies project, students have collected batteries for recycling in collaboration with Supermercados Wong, S.A. (S. Kemme, teacher, Colegio Roosevelt, 
Lima, written commun., February 24, 2007) (fig. 9). Batteries from Supermercados Wong, S.A., Colegio Roosevelt, and other sources are collected monthly by Teconec, S.A.C, an environmental consulting company; however, at present there are no battery recycling facilities in Peru, and Teconec, S.A.C. is researching storage or possible export of the batteries for recycling (Teconec, S.A.C., 2007; A. Knell, manager, Teconec, S.A.C., oral commun., February 22, 2007).

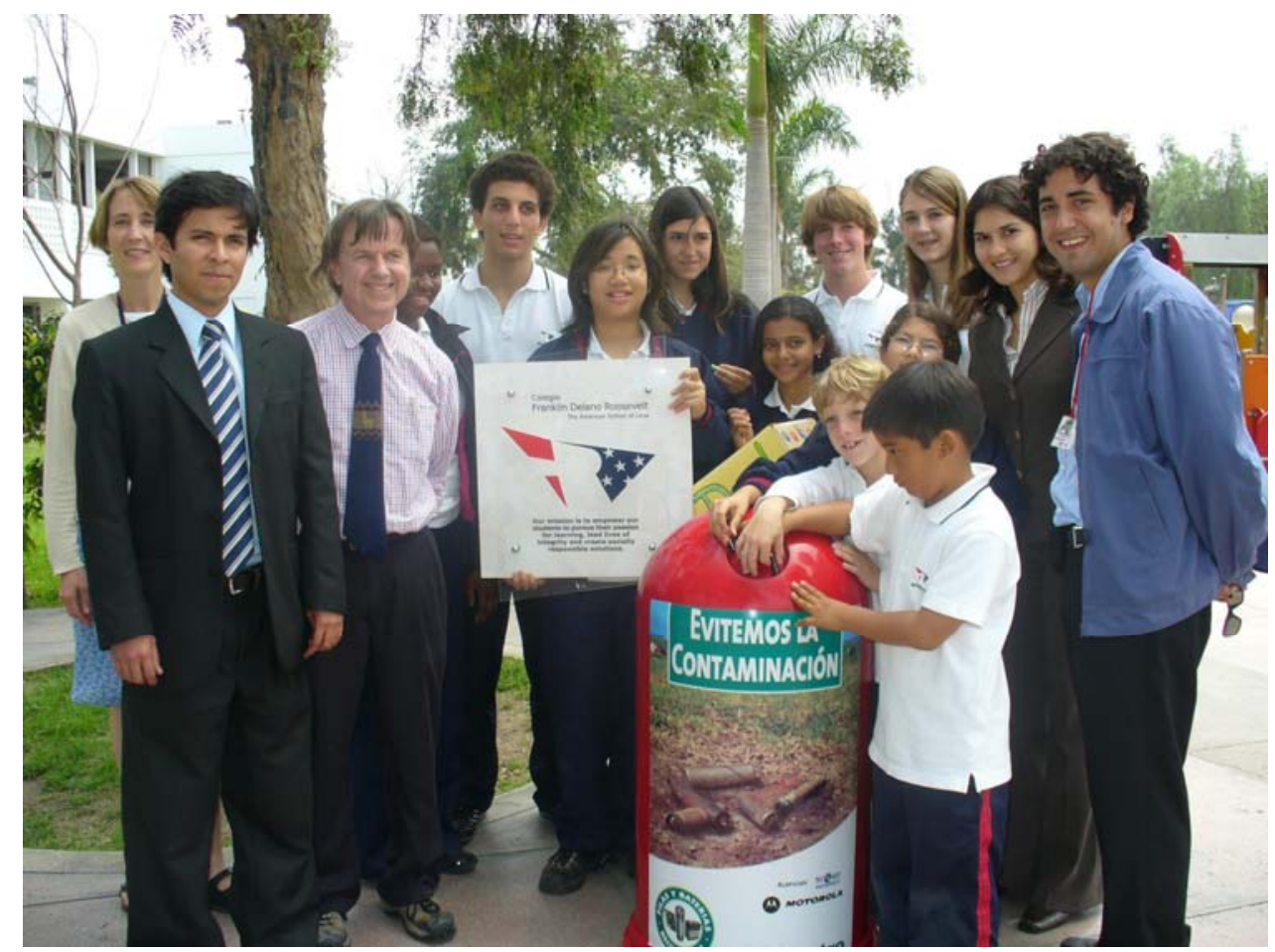

Figure 9. Battery collection for recycling, an environmental project by students at Colegio Roosevelt, Lima, Peru in collaboration with Supermercados Wong, S.A., a major grocery chain and Teconec, S.A.C., an environmental consulting firm in Lima, Peru. (Photograph courtesy of Sarah Kemme, instructor, Colegio Roosevelt, Lima, Peru)

In 2006, a minimum of 2,960 $\mathrm{t}$ of batteries of a wide variety of descriptions were imported into Peru. According to Environment Canada (2007), batteries may contain from 5 to $25 \mathrm{mg}$ of mercury as mercury oxide. Given, an average battery weight of $5 \mathrm{~g}$ for all battery styles (Shenzhen Tech, 2007), a minimum of $5 \mathrm{mg}$ of mercury per battery, and given a zero recycling rate for batteries, then a minimum of approximately $3 \mathrm{t}$ of mercury will ultimately be released after the batteries imported in 2006 are put into the trash.

According to the Canadian Household Battery Industry, mercury in household batteries, especially the button cells, will be eliminated by 2011 (Recycling Product News, 2006). The Swiss company Batrec, which was founded in 1989, is Europe's leading recycler of mercury-containing materials and it processes more than 3,000 t/yr of batteries, sludges, and other materials (Beck, 2004). The Mercury Recycling Group, which is the largest recycler of mercury in the United Kingdom, has tripled its recycling capacity in response to European environmental legislation (Metal-Pages, 2004). Environmental legislation in Europe has resulted in the European Union Battery Directive which is expected to result in a $\$ 640$ million market for recycled batteries (Vollrath, 2006). 


\section{Electronics and Computers}

Electronics and computers may be recycled in order to recover the lead, mercury, and other metals that can be harmful if dumped in a landfill. However, the cost to recycle a computer is approximately $\$ 20$ (S/. 60), and therefore, the recycling rate for the broad category of computers and electronics in the United States is less than 10 percent (Kessler, 2004). On its model MA6, Gateway Inc. includes a label indicating that the lamp in the display contains mercury and should be disposed of in accordance with local, state, and federal laws.

There is no recycling of computers in Peru. Used U.S. Embassy computers may be given to local schools. For the most part, used computers and electronics may be passed from one agency to local schools or refurbished and resold in the used computer district in Lima, the 400 to 500 block of Avenida Wilson. Used computers may also be resold so that the gold contained in the microprocessors may be recovered.

\section{Fluorescent Lamps}

In the United States, reclamation of mercury from spent fluorescent lamps and mercury-vapor lamps began in 1989. The startup recycling rate was 10 to 12 percent, and that rate had increased to about 20 percent by the end of 2000 and each lamp may contain from 10 to $20 \mathrm{mg}$ of mercury (Zero Mercury Campaign, 2002; National Electrical Manufacturers Association, 2003; Environment Canada, 2007). Fluorescent lamp packages in the United States have an information panel that has the symbol for mercury "Hg" and a statement that the lamp contains mercury and should be disposed of in accordance with disposal laws. A website (http://www.lamprecycle.org) and a telephone number (1-800-435-4448) are provided for further information. The U.S. Embassy purchases fluorescent lamps from General Electric, Canada, in 36 unit boxes (F32T8-SP65-ECO). These lamps are marked as containing mercury; however, end-of-use lamps are not recycled and go into the trash.

Fluorescent lamps and the newer energy-saving compact fluorescent lamps (CFLs) are widely promoted and used in Peru and, in 2006, approximately 1,900 t of fluorescent lamps of all types were imported. A site visit to Ace Hardware in Lima (January 31, 2007) showed that this total included a wide variety of wattages ( 8 watts to 100 watts) and styles such as traditional tubes, CFLs, and circular lamps which were imported from Canada, China, Brazil, Germany, Hungary, Netherlands, and Thailand. Most, however, were made in China. Some of these lamp packages indicate that mercury is used in the lamps; however, most do not. These lamps are not recycled and end up in the trash (fig. 10) and, enroute to the landfill, are likely broken and mercury is released.

Given that approximately 1,900 t of mercury-containing fluorescent lamps were imported in 2006, an average lamp weight is $250 \mathrm{~g}$, and each lamp contained 10 to $20 \mathrm{mg}$ of mercury, then it is estimated that a minimum of $76 \mathrm{~kg}$ of mercury (using a minimum of $10 \mathrm{mg}$ of mercury per lamp) was contained in the lamps. Since there is no recycling of fluorescent lamps in Peru, the approximately $76 \mathrm{~kg}$ of mercury contained in the 1,900 t of lamps imported in 2006 will be released to the environment when the lamps are ultimately broken.

In 2006, an estimated 150 million CFLs were sold in the United States and these energy-saving bulbs are widely used in Canada, the European Union, and Australia. The CFLs require less electricity than traditional lamps, and manufacturers argue that the CFLs reduce overall mercury in the atmosphere by reducing the amount of coal used, which by implication reduces mercury emissions from coal-fired power plants. The mercury content of these bulbs is approximately 3 to $5 \mathrm{mg}$, and some have as little as $1.2 \mathrm{mg}$ (Von Ahn, 2007). However, since there is no recycling of CFLs or any other fluorescent lamps in Peru, ultimately the mercury from these energy-efficient lamps will be released when the bulbs are broken, either in, or enroute to, the landfills. 


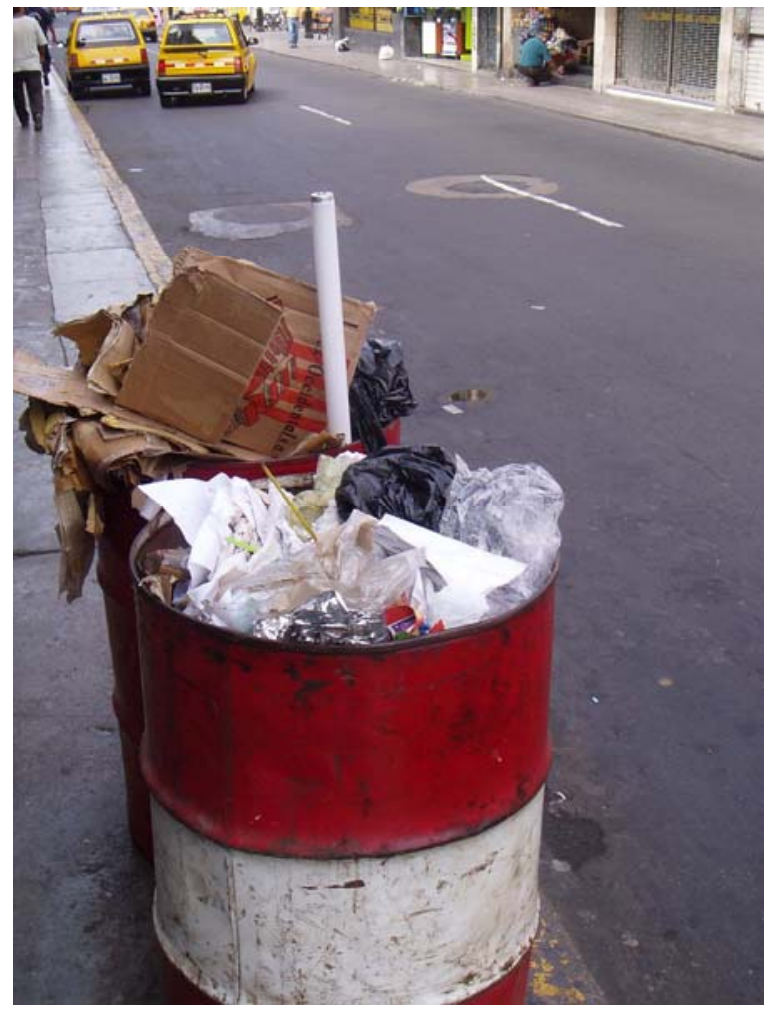

Figure 10. Discarded fluorescent lamp on the street, Trujillo, Peru. (Photograph by William E. Brooks)

\section{Thermometers, Medical Equipment, and Vaccines}

Digital fever thermometers are available in Peru, and mercury thermometers that sell for approximately $\$ 1$ (S/. 3.0) are available in many drug stores. These thermometers were manufactured in China (fig. 11). A minimum of $14 \mathrm{t}$ of thermometers were imported into Peru in 2006 and were used mainly for aquariums, medical use, and refrigeration. Some of these thermometers, if not recycled, may ultimately be broken releasing the mercury in the home, hospital, or to the environment.

\section{SMIC MADE IN CHINA ${ }^{\circ} \mathrm{C}$}

Figure 11. Mercury thermometer bought in a drugstore in Lima, Peru. (Photograph by William E. Brooks)

Mercury-containing blood pressure devices are imported from Germany (Rudolf Riester GmbH \& Co., http://www.riester.de) and are widely sold and used in Peru. Digital blood pressure measuring devices are available; however, the mercury blood pressure cuffs give more reliable readings and are preferred for office use (C. Estrada, nurse, U.S. Embassy, Lima, oral commun., February 22, 2007).

A mercury compound, timerosal, which is used as a preservative in some vaccines, reportedly is a suspected cause of autism in children. As in the United States, in Peru, the relationship between autism in children and mercury in vaccines remained controversial (Harris and O'Connor, 2005; Hightower, 2001). University studies and studies by the Ministry of Health (Peru) present contradictory findings on the health effects of the mercury compound timerosal in vaccines (Izaguirre, 2007; Martinez, 2007). 
Mercury used in thermometers and in blood pressure devices may be recycled; however, at present, there is no collection or recycling of mercury-containing thermometers or medical equipment in Peru. In 2003, however, about $300 \mathrm{t}$ of mercury-containing waste from a closed thermometer plant in India were shipped to the United States for recycling (Rai, 2003). The mercury used as a compound in the vaccine preservative, timerosal, is dissipative.

\section{Prices}

In the global market, mercury is commonly priced and shipped by the $34.5-\mathrm{kg}$ flask, a unique measure that was established at Almaden, Spain, the world's oldest producer of mercury. Information on mercury prices in the global market was compiled from Platts Metals Week, and information on Peruvian import prices was obtained from the Superintendencia Nacional de Aduanas del Peru and from EQUIFAX, formerly known as INFOCORP, a Peruvian company that collects financial data for companies, banks, and individuals that is used for credit sales and loans.

In 2001, the price of mercury was approximately $\$ 155$ per flask, then rose sharply to $\$ 850$ per flask in spring 2005, and settled to approximately $\$ 600$ per flask in 2006 (Platts Metals Week, 2006, p. 19) and early 2007 (Platts Metals Week, 2007, p. 19). The overall rise in mercury prices is in response to: 1) increased demand for mercury for artisanal gold mining in step with increased world gold prices, and, 2) the decline in the production of mercury-containing devices (except for CFLs and other types of fluorescent lamps) and subsequent decline in the supply of end-of-use mercury-containing devices from which mercury may be reclaimed and recycled (Brooks and Matos, 2005).

Virgin mercury is imported into Peru from Spain and Kyrgyzstan and this mercury is preferred for artisanal gold production. The Peruvian import price for this mercury is usually $\$ 20 / \mathrm{kg}$ or higher. Recycled or processed byproduct mercury is imported from Kyrgyzstan (Suerkulov, 2001), the United States, or other sources and the price is somewhat less than $\$ 20 / \mathrm{kg}$. However, some of this recycled mercury may be packaged as to imply Spanish origin in order to obtain a higher price when the mercury is repackaged in 1-kg bottles for sale in the artisanal mining areas.

Byproduct mercury and mercury obtained from processing calomel is also transshipped from the United States, and then held in European warehouses for global distribution (Fialka, 2006). Minor amounts of mercury are also imported from Australia, Austria, Germany and the United States, for dental amalgam and medical uses.

In 2004, Platts Metals Week listed $\$ 365$ per flask (or $\$ 11 / \mathrm{kg}$ ) as the price for mercury in the United States. Peruvian import prices were from $\$ 2$ to $\$ 8$ per kg. In 2005 , mercury sold for $\$ 555$ per flask ( $\$ 16$ per $\mathrm{kg}$ ) and import prices were from $\$ 2$ to $\$ 28$ per $\mathrm{kg}$. In 2006 , mercury sold for $\$ 600$ per flask $(\$ 17$ per $\mathrm{kg}$ ), and import prices were from $\$ 1$ to $\$ 22.20$ per $\mathrm{kg}$. For the first 3 months of 2007, mercury also sold for $\$ 600$ ( $\$ 17$ per $\mathrm{kg}$ ), and import prices were from $\$ 4$ to $\$ 20$ per $\mathrm{kg}$. The uneven nature of import pricing, some of which is well below the international average price per kg of mercury, may be related to country of origin, hedging, whether or not the mercury was recycled or virgin, improper customs declarations, or other reasons.

In 2006 , a $\$ 600,34.5-\mathrm{kg}$ flask (or approximately $\$ 17 / \mathrm{kg}$ ) may easily be worth $\$ 2,100$ or more when repackaged in 1-kg bottles and sold at $\$ 60$ per $\mathrm{kg}$ for artisanal gold mining. Import prices in 2006 per kg of mercury range from a high of \$24 for mercury from Almaden to a low of \$1 for mercury processed in the United States.

In February 2007, in the artisanal mining areas of Huepethue (Madre de Dios) and Ananea (Puno), $1-\mathrm{kg}$ bottles of mercury sold for approximately $\$ 40$ to $\$ 60$ (S/. 120-180) depending on the perceived origin of the mercury. Typically, "El Español," also called "Torito" because of the bullfight scene on the bottle, is the preferred brand and sells for as much as $\$ 60$ (S/. 180) per kg. At some shops in artisanal mining areas, signs are posted that indicate that "good Spanish mercury" is sold. The name and label imply, and users commonly assume that "El Español" is "Spanish mercury;" however, based on distributor contact information on the bottle, Peruvian Customs data show that this is not mercury from Spain and this 
mercury may either be recycled mercury from the United States or virgin or recycled mercury from Kyrgyzstan. Local newspapers, such as "El Minero Artesanal" carry advertisements for mining supplies, quimbaletes, and azogue.

A 100-g plastic bottle of triple-distilled mercury, marked as imported from the United States, and sold in one of the many dental supply stores in the 200 block of Av. Emancipación in Lima cost approximately \$7 (S/. 22) in February 2007.

In artisanal mining areas in nearby Brazil, a kilogram of mercury may sell for as much as $\$ 250$ (L. Fernandez, regional specialist, U.S. Environmental Protection Agency, Washington, D.C., oral commun., August 28, 2007).

\section{Mercury Stocks}

The Government of Peru maintains no stockpile of mercury (M. Yepez, economist, oral commun., U.S. Embassy, Lima, February 8, 2007); however, for comparison, 4,436 t of mercury are held by the Defense Logistics Agency (U.S. Department of Defense) and 1,206 t of mercury left from 1950s research on lithium isotopes for bomb production are held by the U.S. Department of Energy. Approximately 3,000 $\mathrm{t}$ of mercury is held in the cells of the remaining 9 mercury-cell chlor-alkali plants in the United States.

Mercury-cell technology is used by Quimpac S.A., a major supplier of chlorine and caustic soda; however, the amount of mercury in the cells, or stocks, was not available (Isias Flit, advisor, Quimpac S.A., oral commun., February 14, 2007). An unknown amount of mercury was on hand at dental supply shops, dentists' offices, and importers and suppliers of mercury for artisanal gold mining.

\section{Other Mercury Releases and Uses}

\section{Cremation}

Mercury fumes may be released from mercury-silver dental amalgam during cremation, and crematoriums in the United States may emit as much as $145 \mathrm{~kg} / \mathrm{yr}$ of mercury (Chea, 2007). A study of mercury and the cremation process in the United Kingdom indicated that approximately $11 \mathrm{~kg}$ of mercury was released from one crematorium chimney in 1 year (Mills, 1990). A site visit to a funeral agency in Trujillo indicated that cremation was not commonly used in Peru; however, the deceased's family had the right to make the decision regarding removal of gold, platinum, or silver dental work from the deceased. During the time of the site visit, cremations were suspended because the fuel used gave an undesirable black smoke (Jorge Garcia, administrator, Cementerio de Miraflores, Trujillo, oral commun., February 5, 2007). Mercury released from amalgam during cremation was not a concern.

\section{Fireworks}

Studies in Stockholm, Sweden, in 1996 showed that airborne levels of mercury, cadmium, lead, and other metals were 4 to 5 times higher than normal after a fireworks display (Fireworks, 2007; U.S. Fireworks, 2007). Fireworks are made and sold in clandestine shops in Lima and in Juliaca. A fire at one of these shops in Lima in 2001 resulted in the deaths of 250 people (Stevenson, 2001). There is no information on the quantity of metals or metal compounds on hand that are used to color locally made fireworks. 


\section{Laboratories}

School chemistry labs and other laboratories may have stocks of mercury on hand in thermometers, hygrometers, or in bulk. Releases of mercury from broken thermometers is a concern because mercury readily volatizes at room temperature (Putman, 1972, p. 513). For example, mercury from a Washington, D.C., high school lab was stolen and spread around the school which caused evacuation and closure of the school (Fahrenthold, 2003). An elementary school classroom in Leesburg, Va, was quarantined after grade school children were found playing with mercury (Chandler, 2007). There was no information available on the quantity of mercury held in high school and other labs in Peru.

\section{Landfills}

Site visits were made to landfills, landfill offices, and recycling centers in Lima and Trujillo. At the recycling center for Trujillo, at Km 571 Panamericana Norte, aluminum cans, cardboard, and plastic bottles were separated for recycling. At the Relima "Portillo Grande" landfill, near Lurín (south of Lima), from 1,500 to 2,000 t of waste are received per day from Lima. This is an arid area and this particular landfill has no impermeable plastic layers or a system to trap leachate or test groundwater (Craig and others, 2001, p. 116). Waste material is deposited directly on a clay layer that is estimated to be 70-meters thick. There is a medical waste area where, if identified, some mercury-containing waste material may be placed (Odilon Amado, manager, Relima, oral commun., February 15, 2007). A visit was also made to the Gerencia de Medio Ambiente (Municipalidad de Surco) in Lima, a recycling center where glass and plastic materials are recycled (Julio Dávalos, manager, Gerencia de Medio Ambiente, oral commun., February 15, 2007). In general, at the three sites visited, no provisions are made to remove or recycle mercury-containing materials such as amalgam, batteries, electronic waste, fluorescent lamps, thermometers, or toys.

\section{Neon lights}

Argon, neon, and mercury are used as fill to provide color in neon lighting, and out of 44 lamp styles listed on one website, 37 of these used argon/mercury fill (Depue, 2001; Lite Brite Neon, 2007). These lamps may last 25 years or longer. Neon lights are commonly used at restaurants and casinos in Lima; however, there is no information on the source, stock on hand, or amount of mercury used in these lamps.

\section{Paint}

A site visit to several hardware stores indicated that mercury-containing paints are not used. Mold and mildew, when present, are treated by sealants.

\section{Conclusion}

Mercury has been used for ancient and modern artisanal gold production in Peru, and today mercury is an important byproduct from Peru's large scale gold mines. Releases of mercury occur from artisanal gold mining and from broken fluorescent lamps, batteries, and dental amalgam that are put into the waste stream without reclamation or recycling of the mercury. Much of the mercury used for artisanal gold mining, chlor-alkali production, and the mercury contained in these mercury-containing products could be recycled. However, at present, there are no recycling facilities in place in Peru nor is there legislation in place, or pending, which would require tracking or recycling of mercury. 
Peru is a world leader in precious metals production and has the potential to become a world leader in mercury stewardship. As Peru's byproduct mercury is transported and used internationally, its mercurycontaining waste, with appropriate legislation, could also be sent to recycling centers worldwide for reclamation and recycling of the mercury.

\section{References Cited}

Adrianzen, G., 2005, Capacitación y sensibilización para el uso adecuado del mercurio [Sensible use of mercury]: COSUDE, La Agencia Suiza para el Desarrollo y la Cooperación, Lima, 41 p. [In Spanish.]

Alvarado, B., 1980, Recursos de carbón en Suramerica [Coal resources in South America]: Revue de L'Institut Francais du Petrole, v. 35, no. 2, p. 387-421. [In Spanish.]

American Dental Association, 2006, Best management practices for amalgam waste: American Dental Association Web site at http://www.ada.org. (Accessed August 15, 2006.)

Arana, P.P., 1901, Las minas de azogue del Peru [Mercury mines of Peru]: Imprenta El Lucero, Lima, 109 p. [In Spanish.]

Barrick Gold Corporation, 2005, Reporte de responsibilidad [Responsibility report]: Barrick Gold Corporation, Toronto, 28 p. [In Spanish.]

Battery-Index, 2003, Mercury batteries: Battery-Index Web site at http/www.battery-index.com (Accessed June 2, 2003.)

Beck, Manfred, 2004, Batrec, recovering metals: Recycling International, no. 4, May, p. 24-26.

Bowen, S., 2001, Cheap energy, Belgian company opens Peru's first coal utility plant: Latin Trade, February, p. 29-30.

Brooks, W.E., 2007, Mercury, in Metals and minerals: U.S. Geological Survey Minerals Yearbook 2006, v. I, p. 48.1-48.6. (Also available online at

http://minerals.usgs.gov/minerals/pubs/commodity/mercury/myb1-2006-mercu.pdf.) (Accessed May 15, 2007).

Brooks, W.E., and Matos, G.R., 2005, Mercury recycling in the United States in 2000, U.S. Geological Survey Circular 1196-U. (Also available online via http://minerals.usgs.gov.) (Accessed August 27, 2006.)

Brooks, W.E., Finkelman, R.B., Willett, J.C., Gurmendi, A.G., Yager, T.R., Carrascal Miranda, R., and Mucho, R., 2006a, World Coal Quality Inventory-Peru, Chapter 6: U.S. Geological Survey Open File Report 2006-1241. (Also available online at http://pubs.usgs.gov/of/2006/1241/index.html.) (Accessed 15, 2007.)

Brooks, W.E., Piminchumo, V., Suarez, H., Jackson, J.C., McGeehin, J.P., 2006b, Mineral pigments from Tacaynamo, Chan Chan, northern Peru [abs.]: Geological Society of America Abstracts with Programs, v. 38, no. 7, p. 233.

Brown, K.W., 2001, Workers' health and colonial mercury mining at Huancavelica, Peru: The Americas, The Academy of American Franciscan History, v. 57, no. 4, p. 467-496.

Burger, R., and Matos, R., 2002, Atalla, a center on the periphery of the Chavin horizon: Latin American Antiquity, v. 13, no. 2, p. 10-25.

Canepa, C., 2005, Mineria a pequeña escala en la costa sur media del Peru [Small scale mining along the middle southern coast of Peru]: Boletin 3, Serie E: Mineria, Instituto Geológico Minero y Metalúrgico, 79 p. [In Spanish.]

Carrascal, R., Matos, C., and Silva, O., 2000, Carbón en El Peru [Coal in Peru]: Instituto Geológico Minero y Metalúrgico, Boletin 7, serie B, Geologia Económica, Lima, 150 p. [In Spanish.]

Chandler, M.A., 2007, Mercury causes class evacuation: The Washington Post, March 27, p. B5.

Chea, T., 2007, Communities fight crematorium expansion: New York Times Web site at http://www.nytimes.com. (Accessed January, 17, 2007.)

China History Forum, 2006, Tomb of China's first emperor found: China History Forum Web site at http://www.chinahistroyforum.com. (Accessed March 22, 2007.) 
Cox, D.P., and Singer, D.A., eds., 1986, Mineral deposit models: U.S. Geological Survey Bulletin 1693, $379 \mathrm{p}$.

Craddock, P.T., 1995, Early metal mining and production: Smithsonian Institution Press, Washington, D.C., 363 p.

Craig, J.R., Vaughan, D.J., and Skinner, B.J., 2001, Resources of the earth: Prentice-Hall, Upper Saddle River, N. J., 520 p.

Davis, Eric, 2003, Facts about mercury: Eric Davis Dental at http://www.ericdavisdental.com/facts_and_figures_mercury.htm. (Accessed August 13, 2003.)

De Echave, J., Canadian mining companies' investment in Peru, the Tambogrande case and the need to implement reforms: Mining Watch Web site at http://www.miningwatch.ca/updir/Peru_case_study.pdf. (Accessed April 9, 2007.)

Del Busto Duthurburu, J.A., 1996, La plateria en el Perú [Silvercraft in Peru]: Colección Enrico Poli, Banco Sur del Perú, Cuzzi y Cia, S.A., Lima, 357 p. [In Spanish.]

De Lavalle, J.A., 1992, Oro del antiguo Perú [Gold of ancient Peru] Banco de Credito del Perú en la Cultura, Lima, 350 p. [In Spanish.]:

del Carmen Piazza, Maria, 2001, Children working in small-scale traditional gold mining in Peru: Department of the Interior Web site at http://www.dol.gov/ilab/grants/sga0204/SouthAmericaMiningAnnex43.pdf. (Accessed June 20, 2007.)

Depue, S., 2001, How do neon lights work?: Science American Web site at http://www.sciam.com. (Accessed March 27, 2007.)

DeVito, S.C., and Brooks, W.E., 2005, Mercury, chapter in Kirk-Othmer Encyclopedia of Chemical Technology, 5th ed. (Accessed August 27, 2006, via http://www.mrw.interscience.wiley.com.)

Diario Gestíon, 2007, Preocupacion por contaminación ambiental de minera informal [Preoccupied by environmental contamination from small scale mining]: Diario Gestíon, Diario de Economía y Negocios (Lima), February 26, p. 24. [In Spanish.]

D'Itri, P.A., and D'Itri, F.M., 1977, Mercury contamination, a human tragedy: John Wiley and Sons, N. Y., $311 \mathrm{p}$.

Dunin-Borkowski, E., 1996, Minerales industriales del Perú: Instituto Geológico Minero y Metalúrgico, Lima, Peru. 166 p. [In Spanish.]

El Comercio, 2002, Pilas de mercurio intoxican chibolos [Mercury batteries sicken children]: El Comercio Web site at http://www.elcomercioperu.com.pe. [In Spanish.] (Accessed January 15, 2003.)

El Comercio, 2003, Pilas dejan ciegos a chibolos [Batteries blind children]: El Comercio Web site at http://www.elcomercioperu.com.pe. [In Spanish.] (Accessed August 12, 2003.)

El Comercio, 2006, Alertan sobre inminente derrumbe de cerro en Puno [Landslide alert en Puno]: El Comercio Web site at http://www.elcomercioperu.com.pe. [In Spanish.] (Accessed April 4, 2007.)

El Minero Artesanal, 2007, Minera artesanal en Madre de Dios moviliza US\$800 a 900 millones de dolares [Artisanal mining in Madre de Dios generates US\$800 to 900 million dollars]: El Minero Artesanal (Lima), January 27, p. 7. [In Spanish.]

El Peruano, 2007, Buscan formalizar minería artesanal [Looking to formalize artisanal mining] [In Spanish.]: El Peruano Web site at http://www.elperuano.com.pe. (Accessed May 21, 2007.)

Environment Canada, 2007, Mercury and the environment: Environment Canada Web site at http://www.ec.gc.ca. (Accessed March 30, 2007.)

Fahrenthold, D.A., 2003, Mercury is stolen and spread at Ballou High: The Washington Post, October 3, p. B5.

Fialka, J.J., 2006, How mercury rules designed for safety end up polluting: The Wall Street Journal, April 20, p. A1.

Finkelmam, R.B., Warwick, P.D., and Pierce, B.S., 2001, The world coal quality inventory: U.S. Geological Survey Fact Sheet FS-094-00, 2 p.

Fireworks, 2007, Fireworks and asthma: Stop Fireworks Web site at http://www.stop-fireworks.org (Accessed March 21, 2007.) 
Galloso, A., Steinmuller, K., and Pari, W., 1996, Evaluación geológico-minera por oro y dispersión de mercurio en el Rio Madre de Dios [Geologic evaluation of gold mining and mercury releases in the Madre de Dios River]: Instituto Geológico Minero y Metalúrgico, Informe A-5085, 52 p. [In Spanish.]

Gammons, C.H., Slotton, D.G., Gerbrandt, B., Weight, W., Young, C.A., McNearny,R.L., Camac, E., Calderon, R., and Tapia, H., 2006, Mercury concentrations of fish, river water, and sediment in the Rio Ramis-Lake Titicaca watershed, Peru: Science of the Total Environment, v. 368, p. 637-648.

Guerra, L., 2007, La minería informal amenaza al valle piurano de Tambogrande [Small scale gold mining threatens Tambogrande Valley in Piura]: La Republica (Lima), February 26, 2007, p. 12. [In Spanish.]

Gugliotta, G., 2004, Limiting mercury pollution is focus of hot debate: The Washington Post, March 15, p. A3.

Gurmendi, A.G., 2006, The mineral industry of Peru, in Area Reports-International -Latin America and Canada: U.S. Geological Survey Minerals Yearbook 2004, v. III, p. 15.1-15.16. (Also available online at http://minerals.usgs.gov/minerals/pubs/country/2004/pemyb04.pdf.) (Accessed December 15, 2006.)

Harris, Gardiner, and O'Connor, Anahad, 2005, On autism's cause, it's parents vs. research: The New York Times, June 25, p. A1.

Hightower, Jane, 2001, Mercury and autism in children: San Francisco Medical Society Web site at http://www.sfms.org/sfm/sfm401b.htm (Accessed May 8, 2003.)

Hruschka, Felix, 2007, New approaches to safer amalgam burning within the cultural context of artisanal miners in Peru and Ecuador: Communities and Small-Scale Mining Web site at http://www.casmsite.org/Documents/DC-Hg-07-Hruschka.pdf. (Accessed January 26, 2007.)

Izaguirre, Alonso, 2007, Piden retiro de vacunas que contienen mercurio [Vaccines that contain mercury should not be used]: Peru21 (Lima), February 15, p. 12. [In Spanish.]

Kaufmann Doig, Federico, 1978, Manual de arqueologia Peruana [Manual of Peruvian archaeology] Lima, Peru, 800 p. [In Spanish.]:

Kuramoto, J.R., 2001, Artisanal and informal mining in Peru: World Business Council for Sustainable Development and International Institute for Environment and Development, Mining, Minerals and Sustainable Development Project [Working Paper] 82, 53 p. (Accessed February 18, 2007, available online Sept. 11, 2007, at http://www.iied.org/mmsd/mmsd_pdfs/asm_peru_eng.pdf.)

Kessler, M., 2004, Office Depot will recycle old PCs, USAToday, July 13, p. 4B.

La Hora, 2007a, Peligrosa fiebre de oro [Dangerous gold fever]: La Hora (Piura), March 27, p. 4. [In Spanish.]

La Hora, 2007b, Envenenando las aguas [Contaminating the waters]: La Hora (Piura), March 27, p.6. [In Spanish.]

Larco Hoyle, Rafael, 2001, Los Mochicas, tomo II [The Moche, volume II]: Museo Arqueológico Rafael Larco Herrera, Pueblo Libre, Lima, 350 p. [In Spanish.]

Lawrence, B.J., 1995, Going down for the count: Engineering and Mining Journal, v. 196, no. 3, March, p. 42-43.

Light Brite Neon, 2007, Tecnolux: Light Brite Neon Web site via http://www.litebriteneon.com (Accessed March 27, 2007.)

Maravelaki-Kalaitzaki, N., and Kallithrakas-Kontos, N., 2003, Cinnabar find in Cretan Hellenistic tombs, preservative or cosmetic purposes-4th Symposium on Archaeometry, Hellenic Society for Archaeometry: Hellenic Society of Archaeometry Web site via http://www.archaeometry.gr/eae/HSA.htm. (Accessed August 27, 2006.)

Martinez, César, 2007, Calidad de vacunas del Ministerio del Salud esta guarantizada [Quality of vaccines guaranteed by the Health Ministry]: Peru21 (Lima), February 17, p. 12. [In Spanish.]

Medina Cruz, Guillermo, 2001, Mitigación del mercurio en la mineria artesanal y pequeña mineria aurifera del Perú [Mitigation of mercury used for artisanal and small-scale gold mining in Peru], in [technical works presented at] Jornada Internacional Sobre El Impacto Ambiental del Mercurio Utilizado por la Mineria Aurifera Artesanal en Iberoamerica, Lima, Perú, 26, 27, y 28 de setiembre de 2001: 9 p. [In Spanish.] (Accessed November 21, 2002, available online at http://www.gamaperu.org/jornada-hg/medina.pdf.) 
Mercury in Batteries, 2004, Mercury in household batteries, consumer information: Commonwealth of Massacheusetts Web site via http://www.mass.gov/dep/files/battery.htm (Accessed July 20, 2004.)

Metal-Pages, 2004, Mercury Recycling Group to triple capacity: Metal-Pages Web site via http://www.metal-pages.com (Accessed September 22, 2004.)

Meyers, D.K., 1951, History of the mercury flask: Journal of Chemical Education, v. 28, p. 127.

Mills, A., 1990, Mercury and crematorium chimneys: Nature, v. 346, no. 6285, August 16, p. 615.

Minas y Petróleo, 2006a, Crecimiento explosivo de mineria artisanal en Piura [Explosive growth of artisanal mining in Piura]: Minas y Petróleo, December 28, no. 517, p. 10-11.

Minas y Petróleo, 2006b, Una nueva mina en Puno, mas oro para mas vida [A new mine in Puno, more gold for a better life]: Minas y Petróleo, December 28, no. 517, p. 6-9. [In Spanish.]

Ministerio de Energía y Minas, 2005, Uso y manejo del mercurio [Use and management of mercury]: Ministerio de Energía y Minas, Dirección General de Mineria, Guias Mineras 2005, 18 p. [In Spanish.]

Muelle, J.C., and Wells, R., 1939, Las pinturas del templo de Pachacamac [Paints used at Pachacamac]: Revista del Museo Nacional, v. 8, no. 2, 265 p., Lima, Peru. [In Spanish.]

National Electrical Manufacturers Association, 2003, Lamp recycle: National Electrical Manufacturers Association Web site via http://nema.org/lamprecycle/ (Accessed August 13, 2003.)

Noble, D.C., and Vidal, C.E., 1994, Gold in Peru: Society of Economic Geologists Newsletter, no. 17, p. 6-13.

Nowak, Milton, and Singer, William, 1995, Mercury compounds, in Kirk-Othmer encyclopedia of chemical terminology (4th ed.): New York, N.Y., John Wiley and Sons, v. 16, p. 229-243.

Obregon Rossi, Johnny, 2007, Cuatro mil mineros informales contaminan el medio ambiente [Four thousand artisanal miners contaminate the environment]; El Comercio (Lima), April 22, p. A1. [In Spanish.]

Pendergast, D.M., 1982, Ancient Maya mercury: Science, v. 217, no. 6, p. 533-535.

Petersen, Georg, 1970, Mineria y metalírgia en el antiguo Peru [Mining and metallurgy in ancient Peru]: Arqueológicas 12, Museo Nacional de Antropología y Arqueologia, Pueblo Libre, Lima, 140 p. [In Spanish.]

Petersen, C.R., 1978, Coal resources of Peru, in Kottlowski, F.E., Cross, A.T., and Meyerhoff, A.A., eds., Coal Resources of the Americas, Selected Papers: Boulder, Colo., Geological Society of America, The Geology of North America Special Paper 179, p. 35-42.

Petersen, M., 1979, Graveyard of the quicksilver galleons: National Geographic, v. 156, no. 6, December, p. 850-876.

Platts Metals Week, 2006, Weekly prices: Platts Metals Week, v. 77, no. 22, May 30, p.19.

Platts Metals Week, 2007, Weekly prices: Platts Metals Week, v. 78, no. 22, May 28, p. 19.

Putman, J.J., 1972, Quicksilver and slow death: National Geographic, v. 142, no. 4, October, p. 507-527.

Quimpac S.A., 2005, Quimpac S.A. (Lima) annual report 2005, 123 p.

Raimondi, Antonio, 1878, Minerales del Peru [Minerals of Peru]: Imprenta, Lima. [In Spanish.]

Rai, Saritha, 2003, Hazardous waste is shipped from India to U.S. recycling plant: The New York Times

Web site via http://www.nytimes.com. (Accessed August 27, 2004.)

Recycling Product News, 2006, Canadian household battery industry to eliminate mercury: Recycling Product News, v. 14, no. 7, p. 36.

Roskill Information Services, Ltd., 1990, The economics of Mercury (7th ed.): London, United Kingdom, Roskill Information Services, Ltd., 128 p.

Rytuba, J.J., 2003, Mercury from mineral deposits and potential environmental impact: Environmental Geology, v. 43, no. 3, January, p. 326-338.

Sausa, M., 2007, Daños irreparables por la fiebre del oro [Irreparable harm caused by gold fever]. Perú.21 Web site via http://www.peru21.com. [In Spanish.] (Accessed March 22, 2007.)

Saiget, R.J., 2007, Science trumping tourism in China's Valley of Kings. APF Web site via http://www.afp.com. (Accessed March 22, 2007.) 
Schreiber, D.W., Fontbote, L.L., and Lochmann, D.A., 1990, Geologic setting, paragenesis, and physicochemistry of gold quartz veins hosted by plutonic rocks in the Pataz region: Economic Geology, v. 85 , no. 2 , p. $1328-1347$.

Shenzen Tech, 2007, Ni-Cd, NiMH button cells and packs. Shenzhen Suppower Tech. Co., Ltd. Web site via http://suppower.en.alibaba.com. (Accessed March 30, 2007.)

Spitzer, E.E., 2004, Agreement to halt use of mercury batteries. New York State Web site via http://www.oag.state.ny.us. (Accessed July 20, 2004.)

Stevenson, R.E., 2001, Fireworks explosion sparks Peru fire. Voice of America Web site via http://www.voanews.com. (Accessed April 6, 2006.)

Suerkulov, Emil, 2001, Kyrgyzstan development gateway, mercury production and processing. (Accessed September 8, 2004, via http://eng.gateway.kg/mercury.html.)

Talbot, E.S., 1882, The chemistry and physiological action of mercury as used in amalgam fillings. (Accessed July 10, 2003, via http://www.amalgam.ukgo.com/talbot82.htm.

Teconec, 2007, Teconec, tecnologías y consultorias ecológicas [Teconec, ecological and technological consulting]: Teconec Web site via http://teconec.com. [In Spanish.] (Accessed February 14, 2007.)

Truhan, D.L., Burton, J.H., and Bruhns, K.O., 2005, El cinabrio en el mundo Andino [Cinnabar in the Andean world]: Revista de Antropología 18, Casa de la Cultura Ecuatoriana Benjamin Carrion, Cuenca, Ecuador, p. 193-205. [In Spanish.]

U.S. Fireworks, 2007, CFR 16, chapter II, part 1507, fireworks: U.S. Fireworks Web site via http://www.usfireworks.biz/title16.htm. (Accessed March 27, 2007.)

Veiga, M.M., 1997, Mercury in artisanal gold mining in Latin America. Amazonian Forum on Mercury Contamination of Ecosystems Web site via http://www.facome.uqam.ca/facome/pdf/viega_02.pdf. [In Spanish.] (Accessed May 14, 2003.)

Viega, M.M., and Baker, R.F., 2004, Protocols for environmental and health assessment of mercury released by artisanal and small-scale gold miners: globalmercury.org Web site via http://www.globalmercury.org. (Accessed September 15, 2006.)

Viega, M.M., Metcalf, S.M., Baker, R.F., Klein, B.A., Davis, G.H., Bamber, A.B., Siegel, S.T., and Singo, P.P., 2006, Manual for training artisanal and small-scale gold miners: globalmercury.org Web site via http://www.globalmercury.org. (Accessed September 15, 2006.)

Vollrath, Klaus, 2006, Battery recycling, a billion Euro market takes shape: Recycling International, JulyAugust 2006, no. 6, p. 24-29.

Von Ahn, Lisa, 2007, Mercury in energy-saving bulbs worries scientists: Reuters Web site via http://yahoo.reuters.com (Accessed March 29, 2007.)

Washburn, Charles, and Hill, Eldan, 2003, Mercury retorts for the processing of precious metals and hazardous wastes: Journal of Metals, v. 55, no. 4, p. 45-50.

Wilson, Scott, 2004, Peru's mines dig deep at local discontent: The Washington Post, February 17, p. A13.

Yates, R.G., Kent, D.F., and Concha, J.F., 1955, Geology of the Huancavelica quicksilver district, Peru: U.S. Geological Survey Bulletin 975-A, 45 p.

Zero Mercury Campaign, 2002, Mercury product pushers: Mercury Policy Project Web site at http://mercurypolicy.org/new/documents/ProductpushersNATIONALreport.pdf (Accessed August 13, 2003.)

\section{$\underline{\text { Tables (1-15) }}$}


Table 1. Salient Mercury Statistics ${ }^{1}$

[Metric tons unless otherwise specified; ${ }^{\mathrm{e}}$ Estimated; ${ }^{\mathrm{r}}$ Revised; NA not available or not applicable; --no data [Source: Superintendencia Nacional de Aduanas del Perú]

\begin{tabular}{|c|c|c|c|c|c|}
\hline & 2002 & 2003 & 2004 & 2005 & 2006 \\
\hline \multicolumn{6}{|l|}{ Peru: } \\
\hline Primary production & -- & -- & -- & -- & -- \\
\hline Secondary production, mine byproduct & -- & 19 & -- & 128 & 22 \\
\hline Imports for consumption & 63 & 94 & 84 & 88 & 85 \\
\hline Exports & 124 & 66 & 58 & 105 & 24 \\
\hline Industry stocks, yearend & NA & NA & NA & NA & NA \\
\hline Industrial consumption & NA & NA & NA & NA & NA \\
\hline Price, average, free market (dollars per flask) & 140 & 140 & 365 & 555 & 670 \\
\hline World mine production ${ }^{\mathrm{e}}$ & 1,490 & 1,370 & 1,890 & 1,680 & 1,480 \\
\hline
\end{tabular}

${ }^{1}$ Data are rounded to no more than three significant digits, except prices.

${ }^{2}$ Stocks at consumers and dealers not available. Mine stocks withheld to avoid disclosing company proprietary data.

${ }^{3}$ Source: Platts Metals Week. 
Table 2. Imports and Exports of Mercury, by Country

[Metric tons and thousand dollars; --no data; Source: Superintendencia Nacional de Aduanas del Peru]

\begin{tabular}{|c|c|c|c|c|c|c|c|c|c|c|}
\hline \multirow[b]{2}{*}{ Country } & \multicolumn{2}{|c|}{2002} & \multicolumn{2}{|c|}{2003} & \multicolumn{2}{|c|}{2004} & \multicolumn{2}{|c|}{2005} & \multicolumn{2}{|c|}{2006} \\
\hline & Quantity & Value & Quantity & Value & Quantity & Value & Quantity & Value & Quantity & Value \\
\hline \multicolumn{11}{|l|}{ Imports: } \\
\hline Algeria & -- & -- & -- & -- & 21 & 156 & 4 & 113 & 2 & 45 \\
\hline Austria & -- & -- & -- & -- & -- & -- & -- & -- & (1) & 1 \\
\hline Czech Republic & 2 & 8 & -- & -- & -- & -- & -- & -- & -- & -- \\
\hline Germany & -- & -- & 8 & 50 & 2 & 17 & -- & -- & (1) & -- \\
\hline India & -- & -- & -- & -- & -- & -- & (1) & 1 & -- & -- \\
\hline Japan & (1) & -- & -- & -- & -- & -- & -- & -- & -- & -- \\
\hline Kyrgyzstan & -- & -- & -- & -- & -- & -- & -- & -- & 8 & 160 \\
\hline Mexico & -- & -- & (1) & 3 & -- & -- & -- & -- & (1) & -- \\
\hline Netherlands & 9 & 38 & 2 & 11 & -- & -- & -- & -- & 2 & 38 \\
\hline Spain & 30 & 147 & 44 & 270 & 16 & 124 & 21 & 469 & 19 & 342 \\
\hline United States & 23 & 55 & 39 & 174 & 45 & 84 & 62 & 129 & 54 & 250 \\
\hline Total & 64 & 248 & 93 & 508 & 84 & 381 & 87 & 712 & 85 & 836 \\
\hline \multicolumn{11}{|l|}{ Exports: } \\
\hline Brazil & -- & -- & -- & -- & -- & -- & -- & -- & 1 & 27 \\
\hline Columbia & -- & -- & -- & -- & -- & -- & 3 & 17 & 1 & 4 \\
\hline Ecuador & -- & -- & -- & -- & -- & -- & -- & -- & -- & -- \\
\hline Guyana & -- & -- & -- & -- & -- & -- & -- & -- & 1 & 20 \\
\hline Spain & 106 & -- & 53 & -- & 45 & -- & -- & -- & -- & -- \\
\hline United States & 18 & 13 & 13 & 10 & 12 & 86 & 102 & 1,385 & 22 & 209 \\
\hline Total & 124 & 13 & 66 & 10 & 57 & 86 & 105 & 1,402 & 25 & 260 \\
\hline
\end{tabular}




\begin{tabular}{|c|c|c|c|c|c|}
\hline Use & Importer & Exporter & Country & Quantity & Value $^{1}$ \\
\hline \multicolumn{6}{|l|}{ Artisanal Gold Mining: } \\
\hline \multirow[t]{17}{*}{ Recycled: } & Mercantil S.A. & Millenium Chemical Inc. & Algeria & 2 & $\$ 44,000$ \\
\hline & Mercantil S.A. & Millenium Chemical Inc. & United States & 1 & 16,626 \\
\hline & Triveño Mercury Corporation & Bethlhem Apparatus Company, Inc. & United States & 5 & 81,750 \\
\hline & Torres Rojas Aldo Orlando & Millenium Trading Inc. & United States & 5 & 21,390 \\
\hline & J.H. Minerals & Millenium Trading Inc. & United States & 3 & 10,350 \\
\hline & Torres Rojas Aldo Orlando & Millenium Trading Inc. & United States & 4 & 17,250 \\
\hline & J.H. Minerals & Millenium Trading Inc. & United States & 2 & 6,900 \\
\hline & Triveño Mercury Corporation & U.S. Chemical \& Metal Company & United States & 5 & 23,288 \\
\hline & Torres Rojas Aldo Orlando & Millenium Trading Inc. & United States & 2 & 6,900 \\
\hline & J.H. Minerals & Millenium Trading Inc. & United States & 2 & 6,900 \\
\hline & Triveño Mercury Corporation & NA & United States & 2 & 6,533 \\
\hline & Torres Rojas Aldo Orlando & Millenium Trading Inc. & United States & 2 & 3,892 \\
\hline & Triveño Mercury Corporation & NA & United States & 3 & 7,050 \\
\hline & Torres Rojas Aldo Orlando & Millenium Trading Inc. & United States & 2 & 2,949 \\
\hline & Triveño Mercury Corporation & U.S. Chemical \& Metal Company & United States & 3 & 5,920 \\
\hline & Triveño Mercury Corporation & U.S. Chemical \& Metal Company & United States & 10 & 17,760 \\
\hline & Triveño Mercury Corporation & NA & United States & 3 & 4,472 \\
\hline \multirow[t]{7}{*}{ Virgin: } & M \& M Trading S.R.L. & Minas de Almaden y Arrayanes S.A. & Spain & 3 & 58,930 \\
\hline & M \& M Trading S.R.L. & Minas de Almaden y Arrayanes S.A. & Spain & 3 & 58,930 \\
\hline & M \& M Trading S.R.L. & Minas de Almaden y Arrayanes S.A. & Spain & 2 & 27,775 \\
\hline & M \& M Trading S.R.L. & Minas de Almaden y Arrayanes S.A. & Spain & 2 & 27,775 \\
\hline & M \& M Trading S.R.L. & Minas de Almaden y Arrayanes S.A. & Spain & 2 & 29,465 \\
\hline & M \& M Trading S.R.L. & Minas de Almaden y Arrayanes S.A. & Spain & 2 & 35,275 \\
\hline & M \& M Trading S.R.L. & Minas de Almaden y Arrayanes S.A. & Spain & 3 & 70,595 \\
\hline \multirow[t]{10}{*}{ Recycled and Virgin: } & Mercantil S.A. & Millenium Chemical Inc. & Kyrgystan & 1 & 15,960 \\
\hline & Mercantil S.A. & Millenium Chemical Inc. & Kyrgystan & (2) & 6,650 \\
\hline & Mercantil S.A. & Millenium Chemical Inc. & Kyrgystan & 1 & 15,960 \\
\hline & Mercantil S.A. & Millenium Chemical Inc. & Kyrgystan & 1 & 15,960 \\
\hline & Mercantil S.A. & Millenium Chemical Inc. & Kyrgystan & 1 & 16,124 \\
\hline & Mercantil S.A. & Millenium Chemical Inc. & Kyrgystan & 1 & 16,124 \\
\hline & Mercantil S.A. & Millenium Chemical Inc. & Kyrgystan & 2 & 32,248 \\
\hline & Mercantil S.A. & Millenium Chemical Inc. & Kyrgystan & 1 & $\$ 16,124$ \\
\hline & Mercantil S.A. & Millenium Chemical Inc. & Kyrgystan & 2 & 32,248 \\
\hline & Mercantil S.A. & Millenium Chemical Inc. & Kyrgystan & 1 & 16,124 \\
\hline \multirow[t]{2}{*}{ Chlor-alkali production: } & Kossodo S.A.C. & Productos Quimicos Monterrey, S.A. & Mexico & (2) & 260 \\
\hline & Quimpac S.A. & NA & Netherlands & 2 & 37,410 \\
\hline Dental: & Triveño Mercury Corporation & NA & United States & NA & NA \\
\hline \multirow[t]{5}{*}{ Medical: } & Cimatec S.A.C. & Sigma-Aldrich Chemie GMBH & Austria & -- & 41 \\
\hline & Cimatec S.A.C. & Sigma-Aldrich Chemie GMBH & Austria & (2) & 453 \\
\hline & Merck Peruana S.A. & Merck KGAA & Germany & -- & 58 \\
\hline & Merck Peruana S.A. & Merck KGAA & Germany & -- & 126 \\
\hline & Merck Peruana S.A. & Merck KGAA & Germany & (2) & 230 \\
\hline Total & & & & 86 & 814,775 \\
\hline
\end{tabular}

${ }^{1}$ Free on board.

${ }^{2}$ Less than $1 / 2$ unit. 
Table 4. Import Prices per Kilogram, 2004-2007

[Dollars and kilograms, unless otherwise specified; --no data; Source: EQUIFAX (formerly known as INFOCORP)].

\begin{tabular}{|c|c|c|c|c|}
\hline Purchaser & Value $^{1}$ & Value $^{2}$ & Quantity & $\begin{array}{c}\text { Dollars per } \\
\text { kilogram } \\
(\mathrm{kg})^{3}\end{array}$ \\
\hline \multicolumn{5}{|l|}{ 2004: } \\
\hline Mercantil S.A. & $\$ 156,639.92$ & $\$ 149,838$ & 20,709 & $\$ 7.56$ \\
\hline M \& M Trading S.R.L. & $110,484.98$ & 108,689 & 14,630 & 7.55 \\
\hline DFG Mercury Corporation del Peru E.I.R.L. & $83,304.66$ & 77,854 & 45,232 & 1.84 \\
\hline Quimpac, S.A. & $29,289.99$ & 27,999 & 3,450 & 8.48 \\
\hline \multicolumn{5}{|l|}{ 2005: } \\
\hline J \& C Aurysur S.C.R.L. & $286,535.00$ & 284,022 & 12,765 & 22.44 \\
\hline M \& M Trading S.R.L. & $124,755.00$ & 123,076 & 6,038 & 20.66 \\
\hline Mercantil S.A. & $112,977.72$ & 111,639 & 4,002 & 28.23 \\
\hline Triveño Mercury Corporation & $112,623.53$ & 105,845 & 61,306 & 1.83 \\
\hline Aurimetal E.I.R.L. & $57,375.00$ & 56,796 & 2,588 & 22.17 \\
\hline Corporación Reggiper S.A. & $15,693.90$ & 15,300 & 900 & 17.43 \\
\hline \multicolumn{5}{|l|}{ 2006: } \\
\hline M \& M Trading S.R.L. & $341,971.28$ & 338,210 & 18,975 & 18.02 \\
\hline Mercantil S.A. & $221,163.61$ & 218,385 & 10592 & 20.88 \\
\hline Triveño Mercury Corporation & $152,216.53$ & 146,772 & 31,913 & 4.76 \\
\hline Torres Rojas Aldo Orlando & $55,386.23$ & 52,381 & 15,387 & 3.59 \\
\hline Quimpac, S.A. & $38,311.15$ & 37,410 & 1,725 & 22.20 \\
\hline J.H. Minerals E.I.R.L. & $25,682.25$ & 24,150 & 6,038 & 4.25 \\
\hline \multicolumn{5}{|l|}{2007 (January-March): } \\
\hline M \& M Trading S.R.L. & $89,325.00$ & 88,395 & 5,175 & 17.26 \\
\hline Mercantil S.A. & $22,211.31$ & 21,945 & 1,139 & 19.50 \\
\hline Torres Rojas Aldo Orlando & $20,289.87$ & 19,458 & 4,865 & 4.17 \\
\hline J.H. Minerals E.I.R.L. & $10,955.25$ & 10,350 & 2,588 & 4.23 \\
\hline
\end{tabular}

${ }^{1}$ Including cost, insurance, freight.

${ }^{2}$ Free on board.

${ }^{3}$ Rounded, based on value, including cost, insurance, and freight. 
Table 5. Import Mercury Average Price 2004-2007

[Source: EQUIFAX (formerly known as INFOCORP)]

\begin{tabular}{|c|c|c|}
\hline Year & Dollars per flask & Dollars per kilogram \\
\hline 2004 & $\$ 365$ & $\$ 11$ \\
\hline 2005 & 555 & 16 \\
\hline 2006 & 670 & 19 \\
\hline 2007 (January-March) & 600 & 17 \\
\hline
\end{tabular}


Table 6. Exports of Mercury by Country of Destination

[Metric tons and dollars; Source: Superintendencia Nacional de Aduanas del Perú]

\begin{tabular}{llcc}
\hline Country of Destination/Port & \multicolumn{1}{c}{ Exporter } & Quantity & Value \\
\hline Brazil/Rio De Janeiro & Triveño Mercury & $(1)$ & $\$ 9,208$ \\
& Triveño Mercury & $(1)$ & 9,202 \\
& Triveño Mercury & $(1)$ & 9,000 \\
Colombia/Buenaventura & Triveño Mercury & 1 & 4,000 \\
Guyana/Georgetown & Triveño Mercury & 1 & 20,000 \\
United States/New York & Minera Yanacocha S.R.L. & 6 & 53,654 \\
& Minera Yanacocha S.R.L. & 8 & 65,920 \\
& Minera Yanacocha S.R.L. & 8 & 89,413 \\
\hline \multicolumn{1}{c}{ Total } & & 22 & 208,987 \\
\hline
\end{tabular}

${ }^{1}$ Less than one half unit. 
Table 7. Imports of Fluorescent Lamps by Country

[-- no data]

\begin{tabular}{|c|c|c|}
\hline Country & $\begin{array}{c}\text { Quantity, (metric } \\
\text { tons) }\end{array}$ & $\begin{array}{l}\text { C.I.F. }{ }^{1} \text { Total } \\
\text { (thousands) }\end{array}$ \\
\hline \multicolumn{3}{|l|}{ Imports: } \\
\hline Argentina & (2) & 5,280 \\
\hline Bolivia & -- & 3,462 \\
\hline Brazil & 200 & 638,517 \\
\hline Canada & 3 & 12,361 \\
\hline China & 797 & $3,783,930$ \\
\hline Columbia & 42 & 96,817 \\
\hline Czech Republic & (2) & 1,394 \\
\hline Denmark & (2) & 65 \\
\hline France & 31 & 210,348 \\
\hline Germany & 26 & 218,478 \\
\hline Hungary & 104 & 369,112 \\
\hline Indonesia & 3 & 20,353 \\
\hline Italy & 4 & 44,492 \\
\hline Japan & (2) & 3,758 \\
\hline Mexico & 3 & 5,677 \\
\hline Netherlands & 38 & 205,894 \\
\hline Poland & 441 & $1,418,770$ \\
\hline Republic of Korea & 1 & 9,677 \\
\hline Russia & (2) & 404 \\
\hline Singapore & (2) & 1,208 \\
\hline Spain & (2) & 1,974 \\
\hline Switzerland & (2) & 990 \\
\hline Taiwan & 9 & 27,954 \\
\hline Thailand & 175 & 901,006 \\
\hline United Kingdom & (2) & 1,202 \\
\hline United States & 20 & 115,522 \\
\hline Total & 1,866 & $8,098,645$ \\
\hline
\end{tabular}

${ }^{1}$ Cost insurance freight.

${ }^{2}$ Less than $1 / 2$ unit. 
Table 8. Imports of Fluorescent Lamps by Company

[Metric tons and dollars; --no data. Source: Superintendencia Nacional de Aduanas del Perú]

\begin{tabular}{|c|c|c|}
\hline Company & Quantity & Total value $^{1}$ \\
\hline Philips Peruana S.A. & 1,028 & $\$ 5,417,983$ \\
\hline GE Lighting Peru S.A. & 247 & $1,231,363$ \\
\hline Dekatec S.A.C. & 44 & 290,928 \\
\hline Importaciones Megalo S.A.C. & 101 & 105,054 \\
\hline Comercial Bella-Sur E.I.R.L. & 53 & 90,021 \\
\hline Consorcio Comercial Lung S.A.C. & 13 & 51,506 \\
\hline MHT Corporation E.I.R.L. & 27 & 46,636 \\
\hline Celszen Representaciones S.A.C. & 9 & 45,821 \\
\hline Fenix Trading Soc.Com.De Resp. Ltda. & 22 & 36,507 \\
\hline Ferre Import S.A.C. & 32 & 35,360 \\
\hline Koller S R Ltda. & 16 & 35,233 \\
\hline C\&K Importadores S.A.C. & 9 & 35,156 \\
\hline Comercial Industrial Selva S.A. & 12 & 34,648 \\
\hline Anna Import S.R.L. & 28 & 30,616 \\
\hline Fahan S.A.C. & 8 & 22,299 \\
\hline Representaciones Ferretera S.R.L. & 8 & 20,445 \\
\hline Comercial Vilca S.A. & 10 & 18,840 \\
\hline Southern Peru Copper Corporation & (2) & 17,811 \\
\hline Sun Light S.A.C. & 11 & 16,723 \\
\hline Corporacion E. Wong S.A.C. & 3 & 16,469 \\
\hline J P \& CIA E.I.R.L. & 9 & 14,095 \\
\hline Importaciones Togen S.R.L. & 15 & 13,347 \\
\hline Anicama Correa Daniel & 14 & 13,185 \\
\hline Tech Pak S.A. & & 12,294 \\
\hline Homelight Peru S.A.C. & 2 & 11,600 \\
\hline Peruvian Alliance SOC. Anonima Cerrada & 1 & 10,889 \\
\hline Gulda Agro Selva S.A.C. & 3 & 10,850 \\
\hline Representaciones RAE S.R.L. & 4 & 10,452 \\
\hline Metropolis Import Export E.I.R.L. & 7 & 10,157 \\
\hline J Y J Importaciones S.A.C. & 5 & 9,970 \\
\hline Autorex Peruana S.A. & (2) & 8,720 \\
\hline Sodimac Perú S.A. & 1 & 7,387 \\
\hline Pulsar Import E.I.R.L. & 5 & 7,335 \\
\hline Cruz Montesinos Ricardo Celestino & 9 & 7,322 \\
\hline Minera Barrick Misquichilca S.A. & (2) & 7,124 \\
\hline Invercom Yerat S.A.C. & 5 & 7,019 \\
\hline H Y L Imports S.A.C. & 4 & 6,659 \\
\hline Gonzales Caro Jimmy & 8 & 6,342 \\
\hline La Piramide Importaciones S.R.L. & 8 & 6,269 \\
\hline Perales Huancaruna S.A.C. & (2) & 5,399 \\
\hline Sociedad Quimica Mercantil S.A. & (2) & 5,382 \\
\hline Davisco S.A. & (2) & 5,280 \\
\hline Logic Games Peru S.A.C & (2) & 5,230 \\
\hline EGT Eximport E.I.R.L. & 4 & 4,543 \\
\hline Schonimex S.A.C. & (2) & 3,462 \\
\hline Corporacion Jose R. Lindley S.A. & (2) & 3,373 \\
\hline Arrese Cavero Nancy Aida & 1 & 2,973 \\
\hline Blitzkrieg S.A.C. & 2 & 2,847 \\
\hline CP \& C Comercial S.A.C. & 2 & 2,257 \\
\hline Fajardo Esteves Cesar Augusto & (2) & 2,116 \\
\hline Wing WA S.R.L. & 2 & 2,016 \\
\hline Representaciones Martin S.R.L. & (2) & 1,949 \\
\hline Mixtel S.A.C. & (2) & 1,865 \\
\hline Pisconte Gutierrez Laura Evelyn & 1 & 1,864 \\
\hline
\end{tabular}




\begin{tabular}{|c|c|c|}
\hline Company & Quantity & Total value $^{1}$ \\
\hline Pyetrex S.A. & (2) & 1,671 \\
\hline Distribuidora Y Serv. Graf. Lch E.I.R.L. & (2) & 1,659 \\
\hline NCR Del Perú S.A. & (2) & 1,645 \\
\hline Grupo Fenix E.I.R.L. & 1 & 1,639 \\
\hline Castillo Jimenez Fidencio & 1 & 1,478 \\
\hline Industrias del Envase S.A. & (2) & 1,451 \\
\hline Windows Business Import Export E.I.R.L. & 1 & 1,413 \\
\hline Compania de Servicios cosmos S.A. & (2) & 1,363 \\
\hline Fluor Daniel Sucursal del Perú & (2) & 1,355 \\
\hline Variedades Yhelsin' S.R.L. & 1 & 1,334 \\
\hline Quebecor World Perú S.A. & (2) & 1,300 \\
\hline Lighting Camera S.A. & (2) & 1,225 \\
\hline Hilite S.A.C. & (2) & 1,224 \\
\hline Centro Papelero S.A.C. & (2) & 1,175 \\
\hline Electro Daylum E.I.R.L. & 1 & 1,115 \\
\hline Corporacion Fabril de Confecciones S.A. & (2) & 1,047 \\
\hline Cía. Ind. Textil Credisa-Trutex S.A. & (2) & 990 \\
\hline C.I. Grafinal del Perú S.A.C. & (2) & 939 \\
\hline America Sam S.A.C. & (2) & 925 \\
\hline Video Broadcast S.A. & (2) & 883 \\
\hline Amalur Industrial S.A. & (2) & 850 \\
\hline Banco Continental & (2) & 835 \\
\hline Gloria S.A. & (2) & 735 \\
\hline Lanatta Rivarola Fernando Alberto & (2) & 696 \\
\hline Mullisaca Quispe Teresa & 1 & 683 \\
\hline Hotelera Costa del Pacifico S.A. & (2) & 679 \\
\hline Importaciones E L Figueroa S.R.L. & (2) & 659 \\
\hline Laupa Ayquipa Lucio Eloy & (2) & 638 \\
\hline Specchi Sociedad Anonima Cerrada & (2) & 635 \\
\hline OHMLUX S.A.C. & (2) & 569 \\
\hline Saxon Services del Perú S.A. & (2) & 521 \\
\hline Ferreyros S.A. & (2) & 513 \\
\hline Xerox del Perú S.A. & (2) & 493 \\
\hline Peruplast S.A. & (2) & 425 \\
\hline Obras Y Servicios Petroleros S.A.C. & (2) & 424 \\
\hline Protecnia Amazon S.A.C. & (2) & 413 \\
\hline Datacont S.A.C. & (2) & 412 \\
\hline Importad y Exportadora Ferrochiang E.I.R.L. & (2) & 405 \\
\hline Importaciones \& Tecnologias S.R.L. & (2) & 380 \\
\hline El Tumi Perú S.R.L. & (2) & 370 \\
\hline Eesaperu S.A.C. & (2) & 363 \\
\hline Chen Zhimin & (2) & 316 \\
\hline Importaciones y Representaciones Medico Dental S.R.L. & (2) & 291 \\
\hline Cia. Internacional del Café S.A.C. & (2) & 285 \\
\hline Euro Motors S.A. & -- & 284 \\
\hline Cetres Post-Producciones S.A. & (2) & 279 \\
\hline IBM del Perú S.A.C. & (2) & 278 \\
\hline Valtri S.A. & (2) & 276 \\
\hline Asea Brown Boveri S.A. & (2) & 254 \\
\hline Universal de Desarrollos Electronicos Perú S.A. & (2) & 251 \\
\hline Briggitte Import Export E.I.R.L. & (2) & 250 \\
\hline EECOL Electric Perú S.A.C. & (2) & 232 \\
\hline Biocon del Perú S.A.C. & (2) & 228 \\
\hline Triton Trading S.R.L. & (2) & 224 \\
\hline Dicom Ingenieros S.R.L. & (2) & 208 \\
\hline
\end{tabular}




\begin{tabular}{|c|c|c|}
\hline Company & Quantity & Total value $^{1}$ \\
\hline Omega Perú S.A. & (2) & 193 \\
\hline Unitex Global S.A. & (2) & 175 \\
\hline Telvicom S.A. & (2) & 173 \\
\hline G Y M S.A. & (2) & 165 \\
\hline Petro Tech Peruana S.A. & (2) & 161 \\
\hline Empresa Algodonera S.A. & (2) & 157 \\
\hline Dimatic S.A.C & (2) & 153 \\
\hline Química Suiza S.A. & -- & 151 \\
\hline Yap Inga Yandy & 1 & 151 \\
\hline American Industrial Equipment S.A.C. & (2) & 147 \\
\hline Exportimo S.A.C. & (2) & 133 \\
\hline Siemens Building Technologies S.A. & (2) & 116 \\
\hline Guillermo Li S.A.C. & (2) & 114 \\
\hline Exclusive Import S.A.C. & (2) & 111 \\
\hline Laura Janco Jesús Santos & (2) & 107 \\
\hline Import \& Export China Comercial Central S.A.C. & (2) & 102 \\
\hline Topsa Productos Opticos S.A. & -- & 98 \\
\hline Merck Peruana S.A. & -- & 96 \\
\hline Country Home S.A. & (2) & 90 \\
\hline BSH Electrodomesticos S.A.C. & (2) & 83 \\
\hline World Casino Technology E.I.R.L. & (2) & 68 \\
\hline Prelatura de Huari & (2) & 68 \\
\hline Soc.Promotora de Import.Export.S.A.C. & (2) & 67 \\
\hline Sweden Spare Parts S.A.C. & (2) & 62 \\
\hline Corporación Cerámica S.A. & -- & 61 \\
\hline H.W.Kessel S.A.C. & (2) & 60 \\
\hline Tecnología Digital Victoria Perú S.A.C. & -- & 52 \\
\hline Modular Mining Systems Sociedad Comercial de & -- & 51 \\
\hline Heidelberg Perú S.A. & (2) & 46 \\
\hline Machines Los Andes Slots S.A.C. & (2) & 42 \\
\hline Logicorp S.A. & -- & 37 \\
\hline Internacional Colección Cristina S.R.L. & -- & 32 \\
\hline San Fernando S.A. & -- & 32 \\
\hline Peru Office S.A. & -- & 31 \\
\hline Fashionlight S.A.C. & (2) & 29 \\
\hline Tetra Pak S.A. & -- & 29 \\
\hline Servicios Electrónicos Integrales S.A. & (2) & 29 \\
\hline Universidad Peruana Cayetano Heredia & -- & 25 \\
\hline Milano Sport S.A.C. & (2) & 20 \\
\hline America Ret Maquinarias S.A.C. & (2) & 19 \\
\hline Epson Perú S.A & (2) & 18 \\
\hline Indio Feliz E.I.R.L & (2) & 16 \\
\hline Evolution Games S.A.C. & -- & 16 \\
\hline Marmolería Gallos S.A. & (2) & 15 \\
\hline Sony Sucursal del Peru & -- & 13 \\
\hline Senwest International S.R.L. & (2) & 11 \\
\hline Atronic Perú S.A. & -- & 10 \\
\hline ZS Motor S S.A.C. & (2) & 10 \\
\hline Millennium Game S.A.C. & (2) & 8 \\
\hline Team Computer S.A.C & -- & 6 \\
\hline Turbogeneradores del Perú S.A.C. & -- & 3 \\
\hline Club de Leones de Iquitos & -- & 1 \\
\hline
\end{tabular}

\begin{tabular}{l}
\hline Total $^{3}$ \\
${ }^{1}$ Including cost, insurance, freight. \\
${ }^{2}$ Less than $1 / 2$ unit. \\
3Data are rounded to no more than three significant digits; may not add to totals shown.
\end{tabular}


Table 9. Imports of Non-Electric Thermometers by Company

[Metric tons and dollars; --no data]

\begin{tabular}{|c|c|c|}
\hline Company & Quantity & Total value $^{1}$ \\
\hline Empressa Eléctrica de Piura S.A & 1 & $\$ 179,037$ \\
\hline Asea Brown Boveri S.A. & (2) & 70,629 \\
\hline Banco Internacional del Perú-Interbank & (2) & 70,475 \\
\hline Industrial Control's S.A.C. & 1 & 39,091 \\
\hline Petro Tech Peruana S.A. & (2) & 35,663 \\
\hline Consultec y Servicios S.A. & 1 & 33,513 \\
\hline Corporacíon Infarmasa S.A. & (2) & 27,405 \\
\hline Emp Reg de Serv Público de Electricdad & (2) & 21,004 \\
\hline Rash Perú S.A.C. & 1 & 15,961 \\
\hline Importécnia S.A. & (2) & 14,411 \\
\hline Josiel S.A.C. & 1 & 12,787 \\
\hline Banco de Crédito del Perú & (2) & 11,933 \\
\hline Ferreyros S.A. & (2) & 11,684 \\
\hline Mitsui Maquinarias Perú S.A. & (2) & 11,371 \\
\hline Energia del Sur S.A. & 1 & 10,961 \\
\hline Valvulas & (2) & 10,389 \\
\hline EPLI S.A.C. & (2) & 10,099 \\
\hline Motores Diesel Andinos S.A.- Modasa & (2) & 9,530 \\
\hline Controlmatic S.A.C. & (2) & 8,770 \\
\hline Metso Minerals ( Perú ) S.A. & (2) & 7,673 \\
\hline Sandvik del Perú S.A. & (2) & 7,582 \\
\hline Duke Energy International Egenor S.A.-Egenor S.A. & (2) & 7,269 \\
\hline Omega Perú S.A. & (2) & 6,591 \\
\hline Logytec S.R.L. & (2) & 6,459 \\
\hline Textil el Amazonas S.A. & (2) & 6,113 \\
\hline Gobierno Regional Piura & -- & 5,866 \\
\hline Logindustrias S.R.L. & (2) & 5,416 \\
\hline Industrias EKA del Perú S.A. & (2) & 5,039 \\
\hline Tetra Pak S.A. & (2) & 4,827 \\
\hline Termofix Sociedad Comercial de Responsabilidad Limitada & (2) & 4,530 \\
\hline EMP Concesionaria de Elect de Ucayali S.A. & (2) & 4,529 \\
\hline Importadora Andina E.I.R.L. & (2) & 4,502 \\
\hline Construcciónes Electromecánicas Delcrosa S.A. & 1 & 4,352 \\
\hline Noble Equipment \& Services S.A.C. & (2) & 3,591 \\
\hline Praxair Perú S.A. & (2) & 3,458 \\
\hline Southern Peru Copper Corporation & (2) & 3,439 \\
\hline Gloria S.A. & (2) & 3,431 \\
\hline Prosemedic S.A. & (2) & 3,346 \\
\hline Citibank N.A. Sucursal de Lima & (2) & 3,344 \\
\hline Jose Luís López Aguirre S.A. & (2) & 3,301 \\
\hline Venture Management Consultants Enterprises Peru S.R.L & (2) & 3,244 \\
\hline Refinería la Pampilla S.A. & (2) & 3,068 \\
\hline Complejo Agroindustrial Cartavio S.A. & (2) & 3,041 \\
\hline Inversiones Interamericanas S.A. & (2) & 3,007 \\
\hline M \& M Repuestos y Servicios S.A. & (2) & 2,994 \\
\hline Siemens Building Technologies S.A. & (2) & 2,730 \\
\hline Filamentos Industriales S.A. & (2) & 2,716 \\
\hline Higseg E.I.R.L. & (2) & 2,571 \\
\hline Sullair del Pacifico S.A.C. & (2) & 2,515 \\
\hline International Tool \& Supply del Peru S.A. & (2) & 2,266 \\
\hline Repuestos Nuevos S.A. (RENU S.A. ) & (2) & 2,111 \\
\hline Procesadora de Gas Parinas S.A.C. & (2) & 2,110 \\
\hline
\end{tabular}




\begin{tabular}{|c|c|c|}
\hline Company & Quantity & Total value $^{1}$ \\
\hline Edegel S.A. & (2) & 2,087 \\
\hline AWS Consulting S.A.C. & (2) & 2,079 \\
\hline Ferrier S.A. & (2) & 2,064 \\
\hline Industria Textil Piura S.A. & (2) & 1,968 \\
\hline Aparatos y Conecciónes a Gas S.A. & (2) & 1,909 \\
\hline Pluspetrol Norte S.A. & (2) & 1,908 \\
\hline San Fernando S.A. & (2) & 1,893 \\
\hline G Y M S.A. & (2) & 1,845 \\
\hline Serv y Representaciones Asociadas S.A. & (2) & 1,834 \\
\hline A.B.Importaciones Industriales Sociedad & (2) & 1,784 \\
\hline Science and Technology Training E.I.R.L. & (2) & 1,774 \\
\hline Energotec S.A.C. & (2) & 1,721 \\
\hline Arin S.A. & (2) & 1,619 \\
\hline Generadores de Vapor y Equipos Afines S.A. & (2) & 1,606 \\
\hline Guillermo Li S.A.C. & (2) & 1,571 \\
\hline Eléctrica Optimización S.A. & (2) & 1,553 \\
\hline Schlúmberger del Perú S.A. & (2) & 1,539 \\
\hline Classic Chocolat Nelly E.I.R.L. & (2) & 1,254 \\
\hline Fluor Daniel Sucursal del Peru & (2) & 1,372 \\
\hline Aliaga Marro Milágros del Carmen & (2) & 1,295 \\
\hline Lima Caucho S.A. & (2) & 1,247 \\
\hline Gnio Comercial S.A. & (2) & 1,197 \\
\hline Cia. Ind. Textil Credisa-Trutex S.A. & (2) & 1,113 \\
\hline Promotores Eléctricos S.A. & (2) & 1,107 \\
\hline Artículos Importados SRL & (2) & 1,092 \\
\hline Thissen del Perú S.A. & (2) & 1,089 \\
\hline Pluspetrol Perú Corporation S.A. & (2) & 1,078 \\
\hline Masias Marrou Manuel Estuardo & (2) & 1,058 \\
\hline Agrovet Market S.A & (2) & 1,047 \\
\hline Diseños y Equipamientos S.A.C. & (2) & 1,033 \\
\hline Companía Cervecera Aambev Perú S.A.C. & (2) & 986 \\
\hline Samy Import S.R.L. & (2) & 954 \\
\hline Sunshine Export S.A.C & (2) & 927 \\
\hline Nuñez Alarcón E.I.R.L. & (2) & 905 \\
\hline 3M Perú S.A. & (2) & 895 \\
\hline Burns Philp Perú S.A.C. & (2) & 889 \\
\hline V \& Q Instrumentos y Maquinarias Industriales & (2) & 869 \\
\hline Importaciónes Racing S.A.C. & (2) & 792 \\
\hline Pathros Representaciones S.A. & (2) & 771 \\
\hline Unión de Cerveza Peruana Backus y Johnston S.A. & (2) & 749 \\
\hline Texgroup S.A. & (2) & 740 \\
\hline Pesquera Carola S.A.C. & (2) & 726 \\
\hline Fabricá de Cintas Arbona S.A. & (2) & 666 \\
\hline A. Jaime Rojas Representaciónes Generales S.A. & (2) & 651 \\
\hline Marco Peruana S.A. & (2) & 617 \\
\hline Emerson Energy Systems del Perú S.A.C & (2) & 617 \\
\hline Kossodo S.A.C. & (2) & 613 \\
\hline Doe Run PerúS.R.L. & (2) & 612 \\
\hline Importaciónes Gala Empresa Individual de Responsabilidad & (2) & 580 \\
\hline I.C.C. Perú S.A.C. & (2) & 562 \\
\hline Instrumentos y Sistemas E.I.R.L. & (2) & 558 \\
\hline G.R Tech S.A & (2) & 550 \\
\hline NPI Perú S.A.C. & (2) & 546 \\
\hline
\end{tabular}




\begin{tabular}{|c|c|c|}
\hline Company & Quantity & Total value $^{1}$ \\
\hline Mercantil Interamericana S.A. & (2) & 533 \\
\hline Importaciónes Togen S.R.L. & (2) & 510 \\
\hline Construcciónes Peruanas S.A. & (2) & 488 \\
\hline Diveimport S.A. & (2) & 482 \\
\hline Talleres Reunidos E.I.R.L. & (2) & 474 \\
\hline Textiles Camones S.A. & (2) & 439 \\
\hline Fundición Central S.A. & (2) & 412 \\
\hline Corporación E. Wong S.A.C. & (2) & 407 \\
\hline Motores y Maquinarias S.A.C. & (2) & 405 \\
\hline York International S.R.L. & (2) & 402 \\
\hline Sociedad Minera Cerro Verde S.A. & (2) & 399 \\
\hline Consorcio Neshuya & (2) & 379 \\
\hline Mercantil S.A. & (2) & 351 \\
\hline Saeg Perú S.A. & (2) & 349 \\
\hline Frigorífico de Hielo S.A. & (2) & 347 \\
\hline Alicorp S.A. & (2) & 340 \\
\hline Inchcape Motors Perú S.A. & (2) & 320 \\
\hline Schmalbach-Lubeca Plast.Contai.D.Perú S.A. & (2) & 316 \\
\hline J.A.O.R. Representaciónes E.I.R.L. & -- & 312 \\
\hline Minera Aurífera Retamas S.A. & (2) & 309 \\
\hline Acuario Real S.R.L. & (2) & 306 \\
\hline Servicios Petroleros y Anexos S.R.L. & (2) & 302 \\
\hline Asensores S.A. & (2) & 290 \\
\hline Fuel Injection Cano S.R.L. & (2) & 284 \\
\hline Catalina Huanca Sociedad Minera S.A.C. & (2) & 279 \\
\hline Automotriz General del Peru S.A. & (2) & 268 \\
\hline Geotec S.A. & (2) & 266 \\
\hline Cold International S.A. & (2) & 265 \\
\hline A \& A Representaciónes y Servicios S.R.L. & -- & 259 \\
\hline Petrex S.A. & (2) & 258 \\
\hline M \& M Appliance Parts S.R.L. & (2) & 243 \\
\hline Bionet S.A. & (2) & 233 \\
\hline Maquinaria Nacional S.A. & (2) & 224 \\
\hline Brammertz Ingenieros S.A. & (2) & 215 \\
\hline Mantenimento Industrial y Comercial S.A.C. & (2) & 215 \\
\hline Imcetron S.R.L. & (2) & 209 \\
\hline Robocon Servicios S.A.C. & (2) & 208 \\
\hline Minera Yanacocha S.R.L. & -- & 201 \\
\hline Maersk Perú S.A. O ALCONSA & (2) & 165 \\
\hline Tumi Contratistas Mineros S.A.C. & (2) & 164 \\
\hline Química Service S.R.L. & -- & 160 \\
\hline Cafe Britt Perú S.A.C. & (2) & 153 \\
\hline Igardi Herramientas S.A. & (2) & 149 \\
\hline H Y S International S.A. & -- & 140 \\
\hline Granja Santa Rosa S.A.C. & (2) & 124 \\
\hline Olivera Sulca Lourdes Gloria & (2) & 115 \\
\hline Minas y Concentradoras S.A. & (2) & 114 \\
\hline M I Overseas Limited Surcursal del Peru & (2) & 112 \\
\hline Instruments Lab S.A.C. & (2) & 108 \\
\hline General House de Comercio Industrial S.A.C. & (2) & 105 \\
\hline Cemento Andino S.A. & (2) & 98 \\
\hline Meg Energy S.A.C. & (2) & 97 \\
\hline
\end{tabular}




\begin{tabular}{|c|c|c|}
\hline Company & Quantity & Total value $^{1}$ \\
\hline Bradley MDH S.A.C. & (2) & 97 \\
\hline Unión de Concreteras S.A & -- & 95 \\
\hline Tognetti S.A. & (2) & 92 \\
\hline Saidel S.A. & (2) & 89 \\
\hline MC Trade S.A.C. & (2) & 84 \\
\hline Volvo Perú S.A. & (2) & 80 \\
\hline Agrogenetica S.A.C. & (2) & 80 \\
\hline Medicos Sin Fronteras Belgica & (2) & 75 \\
\hline Liftoil S.A. Sucursal Perú & (2) & 72 \\
\hline Inversiones Brencar E.I.R.L. & -- & 70 \\
\hline UNIMAQ S.A. & (2) & 70 \\
\hline Sistemas Industriales y Tecnológicos S.A & (2) & 57 \\
\hline Operaciones Arcos Dorados de Perú S.A. & (2) & 57 \\
\hline Inst. Educac. Franklin Delano Roosevelt & (2) & 53 \\
\hline Refrigeración Oscco E.I.R.L. & (2) & 50 \\
\hline Tecnoimagen del Perú S.A. & -- & 49 \\
\hline La Madrid Gonzales Raul Guillermo & (2) & 47 \\
\hline H.W.Kessel S.A.C. & -- & 42 \\
\hline Inversíones Avicolas S.A. & (2) & 37 \\
\hline Alfa Laval S.A. & -- & 33 \\
\hline C \& CC International S.A.C. & (ट) & 32 \\
\hline Glaxosmithkline Perú S.A. & (2) & 32 \\
\hline MGM Consultores y Contratistas Generales S.A. & (2) & 31 \\
\hline Agromotors E.I.R.L. & (2) & 30 \\
\hline Ceyesa Ingeniería Electrica & (2) & 28 \\
\hline Hewlett-Packard del Perú S.A. & -- & 26 \\
\hline Pacific Interproducts S.A.C. & (2) & 23 \\
\hline Digital Peruana E.I.R.L. & (2) & 17 \\
\hline Servimatic S.A.C. & (2) & 16 \\
\hline Spena Fish Aquacultura S.R.L. & -- & 16 \\
\hline BSH Eletrodomesticos S.A.C. & (2) & 14 \\
\hline Artiglas S.A. & (2) & 11 \\
\hline Belnet Perú S.A.C. & -- & 11 \\
\hline Importaciones Dega Empresa Individual & (2) & 10 \\
\hline Tecnología E Ingeñieria de Fluidos S.A.C. & -- & 10 \\
\hline G.W. Yichang \& Cia S.A. & (2) & 6 \\
\hline Química Suiza S.A. & -- & 5 \\
\hline Total $^{3}$ & 14 & 828,950 \\
\hline
\end{tabular}

\footnotetext{
${ }^{1}$ Including cost, insurance, freight.

${ }^{2}$ Less than $1 / 2$ unit.

${ }^{3}$ Data are rounded to no more than three significant digits; may not add to totals
} 
Table 10. Imports of Batteries, Manganese Dioxide, Alkaline

[Metric tons and dollars; Source: Superintendencia Nacional de Aduanas del Perú]

\begin{tabular}{lcc}
\hline \multicolumn{1}{c}{ Country } & Quantity & Value \\
\hline Australia & $(1)$ & $\$ 33$ \\
China & 338 & $3,021,057$ \\
Germany & 2 & 20,135 \\
Indonesia & 2 & 12,012 \\
Japan & 1 & 6,446 \\
Korea, North & $(1)$ & 22 \\
Korea, Republic of & $(1)$ & 1,262 \\
Malaysia & 1 & 25,285 \\
Singapore & 95 & 562,902 \\
Spain & $(1)$ & 373 \\
Switzerland & $(1)$ & 300 \\
United States $^{c}$ Total $^{2}$ & 69 & 562,218 \\
\hline
\end{tabular}

${ }^{T}$ Less than $1 / 2$ unit.

${ }^{2}$ Data rounded to no more than three significant digits may not add to totals shown. 
Table 11. Imports of Other Batteries, Manganese

Dioxide, Alkaline

[Metric tons and dollars; --no data; Source:

Superintendencia Nacional de Aduanas del Perú]

\begin{tabular}{lcc}
\hline \multicolumn{1}{c}{ Country } & Quantity & Value \\
\hline Australia & -- & $\$ 9$ \\
Belgium & -- & 19 \\
China & 7 & 91,831 \\
Germany & $(1)$ & 1,132 \\
Japan & $(1)$ & 765 \\
Malaysia & $(1)$ & 4,502 \\
Taiwan & $(1)$ & 771 \\
United States & 7 & 68,167 \\
\hline \multicolumn{1}{c}{ Total $^{2}$} & 14 & 167,198 \\
\hline
\end{tabular}

${ }^{1}$ Less than $1 / 2$ unit.

${ }^{2}$ Data are rounded to no more than three significant digits; may not add to totals shown. 
Table 12. Imports of Other Batteries, Manganese Dioxide, Cylindrical

[Metric tons and dollars; Source: Superintendencia

Nacional de Aduanas del Perú]

\begin{tabular}{|c|c|c|}
\hline Country & Quantity $^{2}$ & Value \\
\hline Brazil & 248 & $\$ 475,161$ \\
\hline China & 100 & 138,022 \\
\hline Columbia & 1,477 & $2,594,745$ \\
\hline India & 37 & 37,552 \\
\hline Indonesia & 412 & $1,094,244$ \\
\hline Japan & 124 & 138,320 \\
\hline Korea, Republic of & 17 & 22,954 \\
\hline Total $^{1}$ & 2,415 & $4,500,998$ \\
\hline
\end{tabular}

${ }^{1}$ Data are rounded to no more than three significant digits; may not add to totals shown.

${ }^{2}$ Quantity is gross weight. 


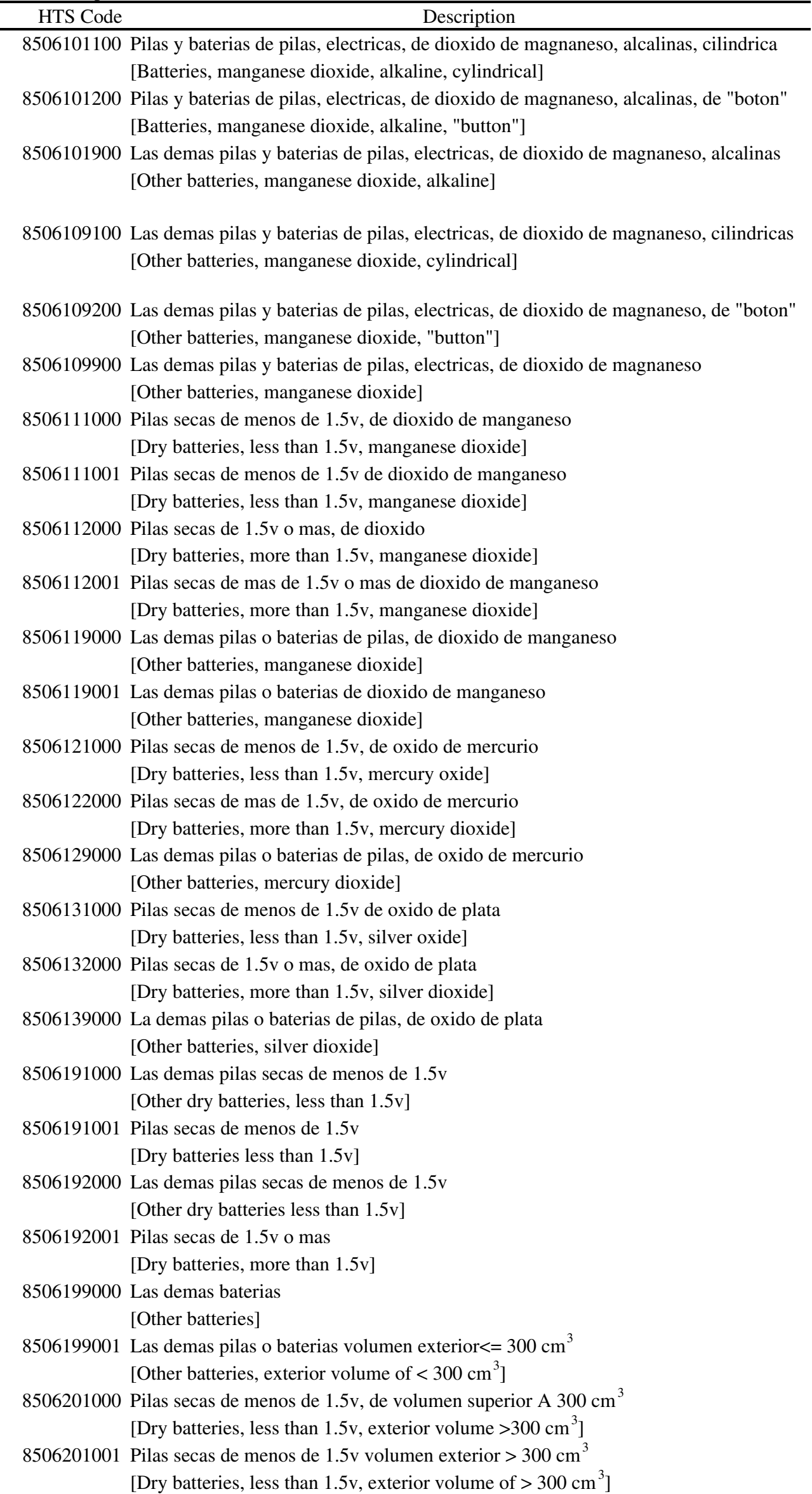


8506202000 Pilas secas de $1.5 \mathrm{v}$ o mas

[Batteries, more than $1.5 \mathrm{v}$ ]

8506202001 "Pilas secas de $1.5 \mathrm{v}$ o mas volumen ex

[Dry batteries, more than $1.5 \mathrm{v}$ ]

8506209000 Las demas pilas o baterias de pilas

[Other batteries]

8506209001 Las demas pilas o baterias de volumen exterior $>300 \mathrm{~cm}^{3}$

[Other batteries, exterior volume of $>300 \mathrm{~cm}^{3}$ ]

8506301000 Pilas y baterias de pilas, electricas, de oxido de mercurio, cilindricas [Batteries, mercury oxide, cylindrical]

8506302000 Pilas y baterias de pilas, electricas, de oxido de mercurio, de "boton" [Batteries, mercury oxide, "button"]

8506309000 Las demas pilas y baterias de pilas, electricas, de oxido de mercurio [Other batteries, mercury oxide]

8506401000 Pilas y baterias de pilas, electricas, de oxido de plata, cilidricas [Batteries, silver oxide, cylindrical]

8506402000 Pilas y baterias de pilas, electricas, de oxido de plata, "boton" [Batteries, silver oxide, "button"]

8506409000 Las demas pilas y baterias de pilas, electricas, de oxido de plata [Other batteries, silver oxide]

8506501000 Pilas y baterias de pilas, electricas, de litio, cilindricas [Batteries, lithium, cylindrical]

8506502000 Pilas y baterias de pilas, electricas, de litio, de "boton" [Batteries, lithium, "button"]

8506509000 Las demas pilas y baterias de pilas, electricas, de litio [Other batteries, lithium]

8506601000 Pilas y baterias de pilas, electricas, cinc, cilindricas [Batteries, zinc, cylindrical]

8506602000 Pilas y baterias de pilas, electricas, cinc, de "boton" [Batteries, zinc, "button"]

8506609000 Las demas pilas y baterias de pilas, elecricas, cinc [Other batteries, zinc]

8506801000 Las demas pilas y baterias de pilas, electricas, cilindricas [Other batteries, cylindrical]

8506802000 Las demas pilas y baterias de pilas, electricas, de "boton" [Other batteries, "button"]

8506809000 Las demas pilas y baterias de pilas, electricas [Other batteries] 
Table 14. Imports of Batteries, Electrical

[Metric tons and dollars; --no data; Source:

Superintendencia Nacional de Aduanas del Perú]

\begin{tabular}{lcc}
\hline \multicolumn{1}{c}{ Country } & Quantity & Value \\
\hline Brazil & 1 & $\$ 6,424$ \\
France & 1 & 281,899 \\
Germany & -- & 49 \\
Indonesia & 16 & 59,998 \\
Japan & $(1)$ & 169 \\
Taiwan & -- & 2 \\
United Kingdom & $(1)$ & 26 \\
United States & $(1)$ & 11 \\
\hline \multicolumn{1}{c}{ Total } & 18 & 348,578 \\
\hline
\end{tabular}

${ }^{1}$ Less than $1 / 2$ unit. 
Table 15. Imports of Batteries, Lithium, Cylindrical

[Metric tons and dollars; --no data]

\begin{tabular}{lcc}
\hline \multicolumn{1}{c}{ Country } & Quantity & Value \\
\hline China & $(1)$ & $\$ 5,104$ \\
France & $(1)$ & 13,871 \\
Germany & $(1)$ & 1,061 \\
Indonesia & $(1)$ & 391 \\
Israel & $(1)$ & 1,518 \\
Italy & -- & 79 \\
Japan & 2 & 43,206 \\
Korea, Republic of & $(1)$ & 1,973 \\
Phillapines & $(1)$ & 1,930 \\
Singapore & $(1)$ & 536 \\
Switzerland & -- & 26 \\
Taiwan & $(1)$ & 86 \\
United Kingdom $_{\text {United States }}^{c}$ & $(1)$ & 76,075 \\
\hline \multicolumn{1}{c}{ Total } & & 101,044 \\
\hline
\end{tabular}

${ }^{1}$ Less than $1 / 2$ unit.

${ }^{2}$ Data are rounded to no more than three significant digits;

may not add to totals shown. 